\title{
4
}

\section{Microfinance and Capacity Building in the EU Policy}

Alessandro Cardente, Perrine Lantoine, Fulvio Pellegrini, Giovanni Nicola Pes, Pasqualina Porretta, Paolo Rita and Fabrizio Santoboni

\subsection{Microcredit in the new EU programmes: the role of the Italian National Agency for Microcredit and the Capacity Building project}

\subsubsection{Microcredit in the new EU programmes}

Microfinance instruments, in particular microcredit, play a key role in the implementation of the European strategies to support entrepreneurship, employment, social and financial inclusion. ${ }^{1,2}$ These instruments, in fact, can support start-ups through the provision of microloans characterised by simplified administrative procedures and absence of collateral requirements, offering to socially excluded and disadvantaged subjects an opportunity to ensure dignified living conditions for themselves and their households. The economic crisis that has hit the European economy in recent years resulted in high social costs that call for the adoption of specific measures to support the weakest segments of the population as well as effectively contribute to the economic recovery through the creation of new development opportunities. Today, individuals at risk are not just those outside the labour market due to disadvantaged conditions, but also other numerous subjects young people, women, immigrants, off-workers, those ejected from the labour market - who, although in possession of professional skills, are unable to enter (or re-enter) the labour market due to a scarce demand for jobs by enterprises and the impossibility to access credit. In this context, the European Commission regards microcredit as a key instrument to fight unemployment and combat the new forms of poverty, to promote access to credit and, more generally, to financial services, a 
necessary condition to fully participate in the social and economic life of the community. A strong expansion of microcredit is, therefore, one of the relevant strategic objectives at European level, also in light of the sheer and growing number of financially excluded subjects. Such need is made even more impellent by the current financial and economic crisis, also because subjects who join new areas of poverty and marginalisation do not represent an appealing market for financial institutions, due to limited profitability, low income and high risk. One of the first EC documents expressly dedicated to microcredit is the communication of 13 November 2007, entitled "European initiative for the development of microcredit to support economic growth and employment", which identifies four priority fields:

(a) improving the legal and institutional environment in the member states;

(b) further changing the climate in favour of entrepreneurship;

(c) promoting the spread of best practices, particularly in relation to training;

(d) providing additional financial capital for microcredit institutions.

As a first step to implement this programme, the European Commission and the European Investment Bank (EIB) took joint action to support microfinance institutions in 2008: JASMINE (Joint Action to Support Microfinance Institutions in Europe), which provides orientation services and financing to non-banking microfinance institutions. In addition, with the EC communication of 3 June 2009, entitled "A shared commitment for employment", the commission stressed the need to offer new opportunities to unemployed individuals and the possibility to create enterprises for some of the most disadvantaged groups in Europe, who struggle to access the traditional credit market. Besides the existing instruments, the commission called for the implementation of specific action to further strengthen economic and social cohesion through the enhancement of the activities carried out by the EIB, the European Investment Fund (EIF) and other international financial institutions, without prejudice to the measures implemented by member states. Consequently, the EC solicited the use of a new European instrument (the microfinance instrument) in order to leverage microfinance to reach out to groups at particular risk and further support the development of enterprises, social economy and microenterprises. This tool helps support those organisations engaged in the social economy 
working with people excluded from the social reintegration process by helping them develop the minimum necessary skills to commit to a long-term entrepreneurial project. Moreover, a microfinance instrument at a European level can maximise the support provided by international financial institutions and avoid a dispersed approach, thus increasing the availability of microloans in all member states. Actions supported by this instrument, starting from the previous EU programming periods, are consistent and complementary with other EU policies, including the former Competitiveness and Innovation programme (CIP), the new programme for the competitiveness of enterprises and SMEs 2014-2020 (COSME), JASMINE, the European Agricultural Fund for Rural Development (EAFRD), the European Social Fund (ESF) and JEREMIE (Joint European Resources for Micro to Medium Enterprises Initiative).

The European Instrument of Microfinance Progress (Progress Microfinance), created in 2010, increases the availability of microloans for the creation or development of small businesses. Although not directly financed by entrepreneurs, Progress Microfinance allows microcredit intermediaries operating in the EU (public and private banks, nonbanking microfinancial institutions, non-profit microcredit providers) to increase their loan volume by providing guarantees to cover the risk of loss and making available further funds for the provision of microloans. This instrument can be used by those willing to start self-employment initiatives or create/develop a microenterprise, especially in the social economy sector, unemployed individuals, those ejected from the labour market, young people, women and, more generally, all those who struggle to access credit.

\subsubsection{The role of the Italian National Agency for Microcredit in the Capacity Building project}

As for the Italian scenario, the Italian National Agency for Microcredit is the public entity, created pursuant to law no. 81 of 11 March 2006, entrusted with the role of promoting microcredit as an instrument to combat poverty and identify measures for the development of financial initiatives aimed at the creation of microenterprises for the benefit of subjects affected by poverty and social exclusion through integrated measures aimed at mitigating the effects of the economic crisis on human capital while protecting the capacity to act and the professional skills of individuals and ensuring social and labour inclusion through access to microcredit. Following different pieces of legislation over time, today the agency is engaged in a number of initiatives aimed at promoting and 
coordinating microcredit and microfinance measures or programmes to be implemented at national and European level. Specifically, the agency:

- acts as the coordinating entity at national level and is entrusted with promotion, guidance, assessment and monitoring of the microfinancial instruments promoted by the European Union, as well as the microfinance activities co-financed by the EU funds (law no. 106 of 12 July 2011, art. 1 paragraph 4bis);

- monitors and assesses all microcredit and microfinance schemes implemented in Italy (Directive of the President of the Council of Ministers of 2 July 2010, published in the Official Gazette no. 220 of 20 September 2010);

- promotes, continues and supports microcredit and microfinance programmes dedicated to the social and economy development of the country, as well as those dedicated to developing countries and economies in transition (microfinance for cooperation), in collaboration with the Ministry of Foreign Affairs (law no. 244 of 24 December 2007, art. 2, paragraphs 185-187).

With regard to its operations, therefore, the activities carried out by the agency can be divided into two operational macroareas: one related to microcredit projects and the other one revolving around instrumental and ancillary services related to the single projects and the microcredit market.

The agency is also engaged in the implementation of the EU programmes JEREMIE, Progress micro-finance and JASMINE, dedicated to the development of microfinance in Europe, in particular playing a contact point role at national level for the programme Progress (EU decision no. 283/2010 of the European Parliament and Council). In this context, the agency supports microfinance operators in the process of accessing EU funds, overcoming issues related to their size and the difficulty of achieving full sustainability. At European level, it advocates the adoption by the commission of legislation that includes business development actions (training, technical assistance, tutoring) in the definition of microcredit. As for its projects, the agency has signed a number of agreements with the Ministry of Labour and Social Policies, as well as with the Department for Public Service, to implement the following projects to be co-financed by the European Social Fund:

- Project "Monitoring the labour policies integration with policies of social development of production systems in the microcredit and microfinance sector" (ongoing); 
- Project "Microcredit and Employment Services - system action for the promotion and creation of innovative operating methods aimed at promoting self-employment and microentrepreneurship at employment service points" (ongoing);

- Project "A.MI.CI - Access to Microcredit for Immigrant Citizens" (ended 2011);

- Project "Capacity Building on financial instruments - definition and experimentation of new skills and tools for efficient programme management, training programme dedicated to the Public Administration" (regions involved in the former convergence programme; ended 30 November 2014).

Strengthening institutional capacity for the planning and management of microcredit and microfinance schemes to support development policies represents one of the most relevant activities of the agency, as this is a pressing need perceived also within the institutional and socio-economic contexts of the so-called advanced economies. The relevant capacity building approach calls for the involvement of an extended number of actors in the design and implementation phases of strategies for growth, one of the thematic objectives of the structural funds programming period 2014-2020, in compliance with the Europe 2020 plan.

In fact, the reform measures adopted in Italy in the last twenty years and aimed at improving the efficiency of the public administration (PA), were not enough to fill all the gaps and, consequently, this situation ended up affecting the socio-economic systems of the weakest regions, in particular those located in Southern Italy. As indicated by the draft partnership agreement for 2014-2020, "The weaknesses of the Public Administration are evident also with regard to cohesion policy management: difficulties in implementing the planning for the 2007-2013 period show excessively slow administrative improvements. The measures to strengthen the administrative capacity already implemented in the previous programming periods, despite offering some important experimentation, in general showed poor effectiveness in promoting a substantial and long-lasting change. Several factors can be pointed out as the reasons behind such delay, including an approach mostly based on the adoption of legislative measures that failed to take in proper consideration the existing skills and expertise within the Public Administration and, therefore, did nothing to strengthen them and promote an organisational change". In general, also according to some international indicators (governance indicators of the World Bank and European Quality of Government Index), there is no clear strategy in place 
to overcome the weaknesses of the Italian administrative system, in particular those related to the effectiveness of the measures co-financed by the EU funds. From the Italian National Agency for Microcredit point of view, capacity building should be a transversal principle to be applied to all strategic planning so as to allow identifying, for each area of intervention, the most suitable mechanisms to improve the administrative capacity of the subjects and structures entrusted with the implementation of the policies. This inevitably entails a complete revision of the public administration organisational model at all levels, including planning, programming and management processes. In this perspective, the exploitation of the additional contribution provided by the structural funds to support the capacity building action is a key factor to drive positive change in the direction proposed. Obviously, optimising the effectiveness of such actions requires an approach able to link the measures promoted by the public administration with the requirements of the underlying social, economic and institutional environment. In other words, to implement successful public policies for socio-economic development through microcredit, it is imperative to build a basic analytical framework, a tool to investigate the reference socio-economic contexts and their needs; the public administration must undergo a comprehensive "restructuring" process according to a competence-based redesign, including the provision of specific skills and expertise. These considerations have been discussed in the preliminary institutional debate for the elaboration of the 2014-2020 programmes, not just with regard to the regional administrations involved in the former convergence programme - the recipients of the capacity building measures activated by the Italian National Agency for Microcredit in the programming period 2007-2013 - but also other institutions operating on the national territory. The European Commission, in its observations on the draft partnership agreement, suggested, among other things, a start to work on the strategy for developing institutional and administrative skills by addressing the critical points first and, in a transversal logic, implementing the general strengthening of the structures entrusted with fund management, with specific focus on a network-type approach and effective use of the partnership. With regard to the capacity building for the public administration, the criticalities identified by the agency can be summarised as follows:

(a) lack of specific know-how on microcredit;

(b) lack of adequate coordination between different operational centres and levels. 
The strengthening of the public administration, therefore, necessarily entails the building of specific skills at different levels, from central to local government authorities, through a variety of dedicated functions and coordination centres. To this end, the capacity building action promoted by the agency aims to invest in the training of the PA personnel through the creation of vertical and horizontal information networks, helping harmonise them and disseminating a technical language that should be shared and used by all the public administration staff involved in planning, designing and management of microfinance activities. This would allow the public administration to strengthen its capacity to interact with the actors operating on the territory. Such is the direction taken by the Italian National Agency for Microcredit, which revolves around the necessity to provide all actors and structures involved in the management of microcredit funds 2014-2020 with key skills and expertise to ensure effective planning, based on defined and measurable results. The agency is committed to creating the conditions for the implementation of microfinance projects dedicated to improving the skills of the public administration personnel and the stakeholders so as to lay the conditions to fully exploit the opportunity offered by the new structural fund framework, namely investing resources through the use of financial engineering instruments in accordance with policies promoting employment and social inclusion.

\subsection{Microleasing, microinsurance, social housing: the new frontiers for European microfinance}

Microleasing, microinsurance and housing microfinance are part of that group of microfinance products and services specifically designed for a target of subjects (microenterprises or individuals) who find themselves in difficult social and economic conditions and struggle to access the traditional banking circuit. ${ }^{3}$ Microfinance supply, not just limited to microcredit, represents an important innovation within the policies promoting financial inclusion, with the involvement of market operators (financial intermediaries and non-profit organisations) as well as public entities entrusted with the implementation of policies for welfare and territorial development (ministries, regional administrations, local government authorities). Although a common opinion trend regards microfinance as a typical feature of developing countries (see, e.g., the enormous success of microinsurance in countries such as India and Bangladesh), developed economies too have seen in recent years a growing popularity of products/services such as microleasing, 
microinsurance, microsavings and housing microfinance, which are implemented according to a modern integrated approach, based on the cooperation of a plurality of public and private subjects. The developed economies have testified the first successful applications of this type of "organised microfinance".

Among the most consolidated experiences in Europe, we must mention France, where the Banque de France systematically monitors the sector through a specific "microfinance observatory", whose reports are published every two years; ${ }^{4}$ this institution promoted a number of qualified conferences on the sector, that is, the meeting organised in Paris in July 2011, to provide a contribution to the G20 policies dedicated to financial inclusion. ${ }^{5}$ In particular, the discussion highlighted the need for extending the range of microfinance instruments by offering a greater number of diversified products and services (microcredit, microdeposits, microsavings, microinsurance, microleasing, payment services) in order to meet the increasing needs and requirements of microenterprises that struggle to access traditional credit or by other subjects in conditions of economic distress. Moreover, besides the supply of financial services/ products, the debate stressed the need for the microfinance institutions to be physically close to the beneficiaries, to activate personal relationships, to seek an operational flexible model, to introduce non-financial services supporting microfinance and, mostly, to include microfinance instruments in policies aimed at fighting social and financial exclusion in order to implement a sustainable growth model.

These are also the guidelines followed by the Capacity Building project ${ }^{6}$ promoted by the Italian National Agency for Microcredit and involving the regions of the former convergence objective, a project co-financed by the European Social Fund. After an initial phase dedicated to the strengthening of the regional microcredit skills, the project focused on the analysis of other microfinance products - specifically microinsurance, microleasing and housing microfinance. Such instruments were comprehensively debated by the natural beneficiaries of the projects, the regional government administrations and the stakeholders, as well as by a number of academics and market operators. The choice of focusing specifically on the three aforementioned microfinance instruments originates from the fact that these instruments are regarded as the most suitable to support the investment plans of the microenterprises (in case of microinsurance and microleasing) or the need to restore/refurbish housing in case of families/individuals affected by harsh living conditions (in case of the housing microfinance), whose activation is based on the involvement of the partnership networks built 
within the Capacity Building project, also for the purpose of using the resources provided by the structural funds in the programming period 2014-2020. The microfinance sector obviously includes also other products/services, such as microsavings, remittances, payment services and transfer of funds, microventure capital, ${ }^{7}$ which are not examined herein. The Italian National Agency for Microcredit has activated a number of workshops with market operators and academics ${ }^{8}$ (2014) to start a public debate on the main issues on microinsurance, microleasing and housing microfinance, and to prepare specific operational proposals for the microfinance sector within the programming period 2014-2020 of the EU structural funds. Below you can find the main considerations that emerged from such debates, in particular during the workshop of 7 April 2014 (see Box 4.1).

Box 4.1 Capacity Building project: initial considerations on microleasing,
microinsurance, housing microfinance

\section{Microinsurance}

In the absence of a specific national regulatory framework providing a univocal definition, "The Italian legislation does not provide, to this date, a univocal definition of microinsurance, as this instrument, unlike microcredit, is not regulated. In fact, while useful regulatory references on microcredit can be found in the provisions of art. 111 of the Consolidated Banking Law, the Insurance Code does not provide any on microinsurance", the phenomenon of microinsurance follows the international guidelines issued by the International Association of Insurance Supervisors (IAIS, 2007), "Issues in regulation and supervision of micro-insurance", June, p. 10. The document can be read at www.irsa.it/get_file.php?id=14420. According to the IAIS, "micro-insurance should not be regarded as a different activity from standard insurance services, except for the reduced amount of premium to be paid, reduced coverage and type of recipients, who are qualified as low-income subjects". For any other aspects, the IAIS does not differentiate it from the traditional insurance business. Following is the literal definition of microinsurance provided by the IAIS: "Micro-insurance is insurance that is accessed by low-income population, provided by a variety of different entities, but run in accordance with generally accepted insurance practices (which should include the Insurance Core Principles). Importantly this means that the risk insured under a micro-insurance policy is managed based on insurance principles and funded by premiums. The micro-insurance activity itself should therefore fall within the purview of the relevant domestic insurance regulator/ supervisor or any other competent body under the national laws of any jurisdiction". For further consideration on this matter, see F. Santoboni, paragraph 4.4. If microinsurance, like microcredit, caters to subjects "excluded" from the 
traditional financial circuits, its potential recipients are "micro-entrepreneurs struggling to access credit, including immigrants, fresh graduates, young people willing to start a business, but also subjects engaged in household activities, who would greatly benefit from an insurance policy, as it would help them corroborate their own businesses". On the supply side, instead, subjects involved in this business are "the traditional insurance companies, including those having a greater commitment to mutual purposes. And then banks, one of the subjects involved in the provision of micro-credit, and, obviously, micro-finance institutions. In principle, if micro-insurance is to be regulated by the same framework applicable to traditional insurance policies, its distribution channels must necessarily coincide with those indicated by the Insurance and Reinsurance Brokers Registry". As for the microinsurance products, in principle, no restrictions are envisaged for their content and scope. First of all, we must consider accident and liability policies, which could be particularly useful, for instance, in case of immigrant microentrepreneurs. After all, we already have insurance policies on the market that, in some cases, can be considered as "eligible" guarantees, therefore perfectly valid for asset allocation deduction purposes. Moreover, there are other policies that, despite failing to meet the eligibility requirements, "would sensibly reduce the chance of default of micro-enterprises and are worth to be considered for creditworthiness assessment purposes, as they would allow borrowers to access credit under more favourable terms and conditions" (F. Santoboni, Adjunct Professor of Economy and Management of Insurance Companies at the Sapienza University of Rome). In particular, CPI (creditor protection insurance) policies are specific products suitable to support loans, as well as other types of insurance contracts, which, as a matter of fact, reduce the general risk profile of a given subject, including property policies, liability policies, business interruption policies and others. These are all obviously tailormade agreements, designed according to the risk profiles of the enterprises, depending on the sectors where they operate.

One of the critical issues here is represented by the low level of financial and insurance literacy among microentrepreneurs. Another weakness is the necessity of reaching a "critical threshold" of "microinsured" subjects, for both technical reasons and the profit margins of the companies. Finally, the reduction of the enterprises' default rate related to insurance coverage at the moment does not translate into improved conditions for access to credit. "When entrepreneurs enter into insurance policies, their profiles become less risky; so, it is hard to understand why they would not benefit from the virtuous relationship between insurance coverage, credit risk and access to credit. In principle, such relation should translate into increased creditworthiness" (Santoboni).

A number of important studies (e.g., a recent survey carried out by ANIA) have highlighted a strong bond between credit and insurance, meaning that small and medium-sized enterprises that enjoy insurance coverage "benefit also from improved access to credit" (F. Palermo, FeBAF, Federation of Banks, Insurance and Financial Companies. In addition, insurance companies can market and sell their microinsurance products also by offering a free check-up on the enterprises' risk or a form of consulting to plan customer insurance needs and requirements. 
One of the strengths of microinsurance is the possibility for the recipients to enjoy national and EU subsidies aimed at lowering the amount of the premium upon signing of the contracts. With regard to this aspect, insurance companies have already a practical experience related to the use of EU funds, specifically with regard to Italian Legislative decree no. 102 of 2004, which allocates EU resources to the agricultural sector by referring to "hail risk". In this case, the state covers up to 80 per cent of the insurance premium, while the remaining 20 per cent must be paid by the insured farmers, as "the aim here is to avoid the so-called moral hazard: if the recipient knows that another subject is covering a risk on his behalf, he will not keep a pro-active conduct to mitigate risk effects. This is to say that when an insurance company decides to enter a market, it must have a competitive advantage; here, the competitive advantage is given not by the EU contributions, as their interest lies in having the premium before the risk, but in the advantage in terms of portfolio stability. If the insurer does not have enough money to ensure risks, the consequent damages will affect not just its business but the whole community of insured subjects that entered into agreements with it, therefore, producing a damage for the entire community". The example of micropolicies against hail risk, mainly entered by the so-called defence associations on behalf of a plurality of farmers, is particularly significant also because it highlights the advantages offered by collective signing. This method, in particular, "allows the insurer to optimize costs and completely cut the brokerage costs it would bear if negotiating the policies with several small farmers on an individualbasis". In fact, low returns on a single product may limit, or in some cases scrap off, the incentive for insurance companies to enter the microinsurance market, although "this downside can be bypassed through the signing of collective policies, which substantially reduce the costs that otherwise insurance companies would meet" (P. Negri, ANIA), http://www.ania.it/it/index. html.

Among the main critical aspects of the sector is "the lack of a specific regulation on micro-insurance, similar to the micro-credit; this is a limiting aspect which creates uncertainties and difficulties to the operators" (Palermo). Moreover, the insurance companies "need to access a number of data, which should be shared among all those engaged into the micro-insurance business: this could definitely make their life easier during the risk assessment phase" (Santoboni); the problem here, in fact, "is to have a defined reference context, where insurance companies are able to access information and data that today they cannot consult" (Negri). Insurance companies, in fact, cannot rely on instruments similar to those used by banks (credit rating, scoring) to evaluate the risk profile of their potential customers and this is why it is increasingly important to have other subjects able to carry out such analysis on their behalf. "Insurance companies build their range of insurance products through a preliminary risk analysis that allows them to operate in relatively safe conditions. If such activity could be carried out by third parties able to ensure the validity of the operations, this would result in a clear advantage for the insurance providers. Here, for instance, we should focus on the role that could be played by the volunteering associations operating on the territory" (Negri). 
There is definitely a widespread interest, both among market operators and insurance academics, in the possibility of defining a package of micropolicies aimed at facilitating financial inclusion of certain target subjects. To this end, therefore, we must keep in account the following factors, which are deemed essential for the development of the microinsurance sector:

1. It is necessary to optimise: (a) administrative costs related to the policies; (b) settlement costs when damages occur; (c) brokerage costs. In fact, in a potential future microinsurance market, administrative and settlement costs related to the policies (adequacy assessment, privacy statement, statements related to IVASS supervision) would be the same as those of standard policies (Negri), http://microcreditoitalia.org/images/pdf/programma07042014.pdf.

2. It is advisable to use collective signing of policies, which would allow reaching out to a greater number of subjects in a timely manner as well as optimising the aforementioned costs (Negri; Santoboni).

3. Insurance companies must be allowed to access comprehensive and detailed information that would enable them to thoroughly evaluate customer risk and creditworthiness during the preliminary assessment phase (Negri; Santoboni). It is recommended that such evaluations be carried out by qualified third parties, as this would result in important cost savings for the insurance providers (Negri).

4. Most critical points, both on the supply and demand side, can be overcome through a microinsurance/microcredit integrated approach suitable to combine the technical features of micropolicies with those of the microloans (Palermo).

5. Increased financial training and literacy is needed, along with greater awareness of the entrepreneurs on the risks associated to their businesses; this would translate into improved creditworthiness and, possibly, cheaper premium amounts (Santoboni; Palermo).

\section{Microleasing}

As with microinsurance, so too microleasing does not enjoy a regulatory framework that allows identification of characteristics that differentiate it from standard leasing, except for the limited amount of operations and the reference target - namely microentrepreneurs most often. Referring to the two classic types of leasing - financial leasing and operational leasing - microleasing mainly falls under the former, which allows redeeming the goods at the end of the contractual period and always involves the intervention of a financial intermediary.

Microleasing and microcredit can be regarded as the two main forms for financing the productive investments of enterprises, the difference between them being the acquisition methods of the goods: in case of leasing, in fact, the lessor remains the owner of the leased goods, while the lessee may opt, upon termination of the contract, to purchase them at market value or renew the contract. Microleasing offers the chance also to microentrepreneurs to invest without the need of using their own capital or debt capital, because the 
basic concept of leasing lies in the separation between ownership of goods and their possession for economic purposes. In addition, leasing offers to henterprises great financial, operational-management and fiscal advantages; in particular, the last are assuming growing importance in Italy thanks to the modifications and simplified procedures introduced by the law for stability of 2014. Law no. 147, of 27 December 2013, published in the Official Gazette of the Republic of Italy, no. 302, of 27 December 2013. On this topic, see Assilea (2014), "Guide to new fiscal provisions for leasing 2014 - the calculation model for the leasing fiscal advantages", January, pp. 7ff.

With regard to microleasing, a first aspect to be clarified is that this product "essentially caters to the so-called entrepreneurial finance, which is constituted by micro-entrepreneurs (artisans, farmers, etc.), rather than the social micro-finance, represented by households and individuals affected by social and economic vulnerable conditions".

As for microleasing's technical and operational features, another issue concerns the redemption option that can be exercised by the lessee upon termination of the contract: "It is an option that can be exercised by the endrecipients, even if the European Commission stated that, in order to be able to enjoy State Aid, the leasing contract must necessarily provide for the redemption of goods. This is why in the notices issued by regional administrations such requirement is often mandatory and this represents a contradiction with the basic principle of leasing. The issue was solved by the Italian Tax and Revenue Agency with Resolution No. 4/E of 2009, which indicated that the appendix of the leasing contract must provide for the commitment of the Lessee, as of now, to redeem the leased goods upon termination of the financial leasing contract" (Palermo).

Another issue raised by the leasing operators relates to the fact that the regional administrations and business associations must establish some guidelines to facilitate the success of microleasing. Such guidelines should also clarify the above-mentioned issues related to the redemption of goods, delivery and testing date, which coincides with the actual date of effectiveness of the leasing contract (Palermo).

More generally, we can observe that any microleasing programme, in order to succeed, must be structured since the beginning through the provision of different kinds of instruments designed according to individual cases and regions, including guarantee funds, revolving funds and grants for payment of leasing instalments. The first issue to be addressed is "how to provide a strong guarantee similar to that offered by the central guarantee funds for the SMEs in terms of coverage percentage: a guarantee that may allow also the credit guarantee consortia to issue counter-guarantee and, in turn, transfer the guarantees upon first request" (Guenzi, Unicredit Leasing; Grillo, Alba Leasing). The second product to be carefully examined, mainly used by leasing companies, is the revolving fund. In this case, "The regional administrations should provide resources at subsidized rate to the leasing companies, and the latter must immediately transfer them to the beneficiary enterprises" (Guenzi). The third product is the contributions for payment of leasing instalments, which is not regarded as a priority by the leasing companies, but can be a useful tool to support enterprises. "These contributions, anyway, should not exceed 15\% and should not be paid in a single solution, in order to avoid recovery problems in case of default" (Guenzi). 
As for possible development of microleasing, we should take into account the following considerations coming from the market operators:

- Leasing companies can carry out low-amount operations for the microenterprises, but they must always operate in terms of costs, expenses and profit and, as such, assess the sustainability of such operations, which entail a number of administrative and management costs (Grillo).

- Regional administrations should act in two ways: first of all, by providing information and tutoring services to microentrepreneurs, so that the latter can operate according to valid criteria recognised by the lenders; in addition, by granting public guarantees (Grillo).

- In order to avoid situations of scarce demand for microleasing products, they should be designed so as to be fully manageable by operators. To this end, it is necessary to organise more opportunities for discussion with all the stakeholders, like those coordinated by the Italian National Agency for Microcredit (Palermo; Grillo).

\section{Housing microfinance}

The microfinance products described so far are characterised by a high degree of social responsibility, as microinsurance, microleasing and housing microfinance must be supported by non-financial services such as coaching, training, monitoring and tutoring, including those financial education services needed to ensure a successful exit process of the beneficiaries from conditions of financial exclusion. The recipients can be individuals willing to start an enterprise or a self-employed activity but also weak, underserved subjects: immigrants, unemployed individuals, young people and others.

It is therefore necessary to think of microfinance in terms of an integrated approach based on the collaboration of public and private entities, including enhanced relationships between the public administration and the banking and financial system in order to verify the concrete opportunity to develop specific products within the operational programmes co-financed by the EU structural funds in the programming period 2014-2020. Besides the technical peculiarities of the instruments, a new and sensible microfinance culture must be encouraged and actively promoted with the aim of offering "integrated packages", where microcredit, microinsurance and microleasing products are simultaneously present. All this entails the collaboration of the interested parties: institutional policymakers, microcredit and microfinance promoters, banking and financial intermediaries, fund managing authorities and non-financial service providers.

Source: Authors' elaboration.

\subsection{Microleasing: introduction and Capacity Building project issues}

In common business practice, "microleasing" generally refers to the leasing of capital goods directed at low-income microentrepreneurs and characterised by small loans (usually not exceeding $€ 25,000$, the same 
amount provided by microcredit). Financial leasing is a contractual arrangement between two parties, which allows one party (the lessee) to use an asset owned by the other (the lessor) in exchange for specified periodic payments. The lessee uses the asset and pays rental to the lessor, who legally owns it (Gallardo, 1997). Microleasing is thus the leasing of assets to the poor to alleviate poverty by enabling those usually unable to access productive assets to generate income. In the main, there are two types of leasing: financial leasing (after the period of leasing, the asset is owned by the lessee) and operational leasing (after the period of leasing, the asset returns to the lessor; Deelen et al., 2003; Goldberg, 2008). Narrowing down the study to the community countries, ${ }^{9}$ it should be noted that, to date, there is no empiric evidence of the development of this financial instrument, in terms of volume of activated contracts, investments, categories of recipients and business sectors involved. This is due both to a lack of specific legislation on microleasing, which does not allow for an objective identification of the phenomenon, and to the scarce availability of scientific studies and specific statistical analysis carried out by research centres and market operators on this subject. Also, the latest international studies on microfinance confirm this conclusion; furthermore, they all highlight the necessity of starting in-depth studies on microleasing. See, for instance, the Report $2012^{10}$ by the EPPI Centre, ${ }^{11}$ The Evidence for Policy and Practice Information and Co-ordinating Centre, on effects generated by microcredit, microleasing and microsavings on financial inclusion of vulnerable subjects, in particular women. This report shows ample evidence of the difficulties and issues that the study's authors met in acquiring information and data on microleasing:

We also used a number of different search terms and so were surprised that we did not identify any relevant studies, let alone good quality ones - none of the 84 studies identified from screening and subject to critical appraisal were about micro-leasing. ${ }^{12}$ We suspect that leasing is an old practice which has only relatively recently been regarded as a micro-finance product and requires services providers to have specific asset management skills. We therefore came to the conclusion that micro-leasing has only recently been included in the group of microfinance products and that it did not enjoy the same visibility and attention that micro-credit and micro-savings had in the last twenty years; as such, it has not been subject to the same evaluative scrutiny. Despite the lack of evidence, the theory suggests that micro-leasing 
may constitute a more effective measure than micro-credit, because lending someone a productive asset such as a bicycle or a market stall rings the borrower one step closer to engaging in economic opportunities than lending someone money. There is therefore an imperative for rigorous research in this area. ${ }^{13}$

The lack of a specific literature on microleasing does not, therefore, indicate a scarce interest for this opportunity by European microenterprises; the operational practice, in fact, shows frequent leasing operations characterised by small amounts to the benefit of small-size businesses and this context certainly includes a consistent number of entrepreneurs who represent the natural recipients of microleasing products. ${ }^{14}$ According to the results of an in-depth survey carried out at European level by Oxford Economics on behalf of Leaseurope (the European federation of the leasing companies $)^{15}$ in July 2011, European SMEs' use of the leasing is quite widespread, especially in those countries, like Italy, where SMEs in particular the microenterprises - represent almost the total of existing enterprises ${ }^{16}$ and, therefore, play a key role in the economy in terms of added value and employment. The survey covered around 3,000 small and medium-sized enterprises engaged in nine different areas of business, from eight European countries (France, Germany, Italy, Holland, Poland, United Kingdom, Spain, Sweden) which, in 2011, represented as a whole 83 per cent of the European economy and 78 per cent of the leasing market in Europe.

According to the survey outcomes, leasing is, after equity and bank loans (regardless of their duration), the third most widespread form of financing among European SMEs, mainly microenterprises. This is followed, in order of importance, by bank loans with a duration of over three years, bank overdraft, commercial credit, bank loans with duration of less than three years, private equity/venture capital and factoring. Moreover, the survey shows that in the period 2010-2011, more than 40 per cent of European SMEs resorted to leasing and, through this instrument, were able to invest in production capacity for an amount of approximately $€ 110$ billion. The manufacturing sector plays a prominent role in the group of leasing customers; it is the most capital-intensive one and the one in which instrumental machinery has strategic importance for the leasing activity. ${ }^{17}$

According to the above figures, there seems to be a strong preference for the use of leasing also by microenterprises, which represent the bulk of the SME universe. Moreover, the leasing contract offers also some 
interesting advantages to small enterprises, both in financial terms and for their operational/management and fiscal aspects. In fact,

(a) from a financial standpoint:

- it allows using the good without tying up the sum needed to buy it;

- it allows funding the entire cost of the good (including VAT);

- it does not affect the creditworthiness of the lessee;

(b) from an operational/management standpoint:

- it provides enterprises with fast and simple access to finance;

- it allows for the opportunity to obtain substantial discounts on the cost of the goods leased thanks to the lump sum payment by the leasing company to the supplier;

- it is a flexible instrument which can be custom-tailored to specific needs and requirements: duration of the contract, frequency and amount of the lease payments, redemption value of the good, provision of additional services, such as technical support, insurance and maintenance;

- it provides for the possibility to purchase the good at the end of the contract according to the terms and conditions set therein;

(c) from a fiscal standpoint:

- it allows deducting the lease payments (both principal and interest);

- it allows splitting the VAT in the periodic payments;

- it may allow, under certain conditions, for an accelerated depreciation compared to the regular depreciation tables, through the deductibility of the periodic lease payments throughout the duration of the contract.

With regard to microfinance, we should consider that a vast number of microentrepreneurs saw their options to access traditional bank loans sensibly reduced, mainly due to the effects of the financial crisis that occurred in recent years; the same occurred for credit supplied by other financial intermediaries, such as leasing companies; many of them, thus, ended up in that grey zone that goes by the name of financial exclusion. All subjects involved in microfinance - policymakers, public administrations, market operators, non-profit organisations, academic and scientific institutions - should therefore develop specific microleasing products to promote the growth of the most vulnerable enterprises, using them as tools to promote financial inclusion and stimulate manufacturing production and the creation of jobs. 
These issues were addressed in Italy by the National Body for Microcredit, which, within the Capacity Building project, kicked off a number of initiatives to promote research projects aimed at designing microfinance products/services, such as microleasing. The studies received positive feedback and indications on the opportunity to start projects for the development of microleasing instruments that may facilitate financial inclusion of those microentrepreneurs unable to access traditional bank loans. In particular, all stakeholders acknowledged the importance of the role played by the National Body for Microcredit to act as a stimulus to solve the issues at stake. Among such issues, the following were specifically raised:

(a) the need for specific microleasing regulations, if not at legislative level, at least in terms of guidelines and operational standards set out by professional associations, to be published in the bulletins of the regional government administrations;

(b) the need to activate training programmes, technical assistance, monitoring and coaching initiatives dedicated to the microenterprises using microleasing; these kinds of activities should also be promoted by policymakers through the involvement of specialised operators;

(c) regional government administrations should create guarantee funds or revolving funds to support microleasing, in order to make this market more attractive to financial intermediaries.

The public administration, in fact, can play a substantial role in terms of stimulating design and development of microleasing products, by leveraging on the operational programmes co-financed by the EU structural funds to promote incentives for investments made through financial leasing, even in conjunction with other financial engineering instruments. In this regard, the creation of guarantee funds or revolving funds financed by national resources represents a best practice for the microleasing and the microcredit alike:

- It can guarantee funds, by reducing the risk of credit operations, often playing a fundamental role in the implementation of microfinance programmes and, in many cases, allow financiers to charge the beneficiaries a lower price; moreover, they improve the sustainability of microfinance programmes and have a positive impact on the capacity to provide financial services to those segments of the population excluded from the traditional banking circuit (outreach).

- With the revolving funds, the public administration (central government or regional government administrations) can provide operators 
with a fund to be used for microleasing operations on concessional terms and with the obligation to transfer this benefit directly to the beneficiary enterprises. In this case, the latter are offered a rate equal to the weighted average between the subsidised funding rate (often equal to zero) and the ordinary lending rate. In addition, revolving funds are self-sustaining instruments as returns from the leasing payments and will accumulate and then be reinvested in other microleasing activities.

Another topic of discussion is the risk assessment to be performed by the leasing companies on the lessee. This type of risk is usually covered by the title on the property of the goods, which remains with the leasing company for the entire duration of the contract and is transferred to the lessee only if and when the latter decides to exercise the redemption option. However, as financial leasing is basically an assetbased lending, it requires that in any case the lessor carefully assess not just the customer credit risk but also the risk connected to the technical and economic obsolescence of the goods on the market. Despite being one of the traditional forms of creditworthiness assessment, if the customer risk assessment is applied to microcredit, it might be affected by some issues related to lack of sufficient data on the credit history of the potential beneficiaries. In this perspective, it would be advisable for leasing companies interested in entering this market to adopt a portfolio management policy which takes into account also the social and economic context of the beneficiaries and provides for flexible lease payment schedules according to customers' income.

However, information asymmetries might potentially complicate the risk-assessment process to be carried out by the financing subjects, due to difficulties to assess businesses, their reference market and their cost structures. A key factor here, just as in the case of microcredit, could be the provision of so-called non-financial services, which allow for an initial screening of the applications submitted to the leasing companies, accompanied then by monitoring and coaching services for the beneficiary enterprises. The provision of such services may prove key to ensure the successful implementation of microleasing schemes, as already experimented with in the microcredit programmes, provided that the subjects entrusted with their provision (whether public or private entities) are carefully selected through clear and transparent tendering procedures and meet highly specialised standards and requirements. These subjects, in fact, are called to implement a number of communication, information, training, technical assistance and coaching actions 
aimed at increasing the level of financial and economic inclusion of the beneficiaries as well as their ability to repay. Just think about, for instance, the importance of the so-called BDS (Business Development Service), which is intended to support the microentrepreneurs during the seeding or start-up phases of their businesses and fill any gaps in terms of professional, financial, economic and technical expertise. These services, therefore, play a highly strategic role, as their objective is to help entrepreneurs develop medium- to long-term planning in financial, management, marketing and operational areas, which are essential to support the daily operations of any business.

As for the above, microleasing can represent an important tool to encourage the development of local productive systems; microentrepreneurs who do not possess the financial means to purchase the goods used in their production may be able to get hold of these assets by way of microleasing agreements without acquiring ownership. In this perspective, microleasing can be regarded as an instrument promoting social and financial inclusion and facilitating the redistribution of resources within a given economic system. Ultimately, microleasing can be either an alternative to microcredit or a complementary tool to be used in conjunction with the latter; it can be used by enterprises that need to make investments exceeding the microcredit limits and were deemed unreliable by the banks. However, as previously mentioned, at the moment there are no experiences that testify with certainty the impact of microleasing on the economic and financial situations of microentrepreneurs (especially the most vulnerable of them) entering microleasing agreements. This is also due to the fact that, in general, it is extremely difficult to isolate the effects that microfinancial instruments (including microleasing) may produce on the economy as a whole as well as on the individual beneficiaries, although a number of authors tried to systematically measure them (Dowla, 2004; Heyn, 2001; Pinder, 2001). Ultimately, the success of any microleasing scheme lies in a savvy policy of portfolio composition, knowledge of customers and constant monitoring and supervision of the evolution of the microleasing contracts.

\subsection{Microinsurance: a solution just for the "developing countries"?}

\subsubsection{Introduction}

Low-income individuals living in risky environments are vulnerable and exposed to numerous perils. These can be related to their life cycle 
or to economic, political and social issues or consist of natural disasters like floods or climate changes (Radermacher and Brinkmann, 2011, p. 63). The poor are more vulnerable to risks than the rest of the population, and they are also the least able to cope when a crisis does occur. Furthermore, poverty and vulnerability happen to reinforce each other in an escalating downward spiral (Churchill, 2007, p. 401). In addition, low-income individuals face numerous further risks as they usually lack access to formal risk-coping solutions, including "conventional" insurance products. As a result, it becomes extremely difficult for such households to manage unforeseen expenditure or loss of income, a situation that renders them highly vulnerable to life, health and financial shocks (Swiss Re, 2010, p. 4). For these reasons, in recent years microinsurance or insurance for the poor - has been receiving an increasing amount of attention from policymakers and researchers due to its potential to assist in alleviating poverty. However, on a practical basis, successful provision of microinsurance products is often hindered by a variety of obstacles, including relatively high administrative costs and limited financial literacy and education among the target population. From this perspective, policymakers around the globe have considered a number of initiatives intended to stimulate the creation of a robust and sustainable insurance industry (Biener et al., 2014, p. 21). Generally, when we speak of microinsurance the obvious reference is constituted by experiences as represented by specific contributions in literature or reports compiled by organisations involved in the microfinance sector, mostly active in North African countries as well as in South America and SouthEast Asia. The common trait of such experiences is represented by the provision of specific insurance policies designed for and tailored upon the needs and requirements of the target clientele - consisting of both low-income individuals and legal entities - that are unable to access the "conventional" insurance market. On the other hand, microinsurance differs from the latter in the type of subjects involved in the design and marketing of its products as well as in the limited amount of premiums paid and, consequently, the coverage provided. Following the experiments carried out in such contexts, in light of what has already happened in the microfinance and microcredit industry, it seems that the time is now ripe to start thinking how to adapt the experiences carried out in the aforementioned financially and economically "disadvantaged" countries to more advanced contexts, catering to the requirements and needs of an increasing number of subjects, who, de facto, are being excluded from the "traditional" insurance market, through the development of a number of proper instruments suitable to meet their 
necessities. All this, in particular, with a priority eye on EU member or candidate countries, although the same considerations and patterns may also apply to other "developed" socio-economic contexts. Moving from this perspective, the present chapter aims to analyse the main features of microinsurance in the countries where it was originally developed and then gradually succeeded while trying to indicate some aspects worth examining in order to apply such solutions within economic and financial systems characterised by a greater degree of "sophistication" and in which a relevant amount of demand for insurance coverage is not met, a situation that could generate ample business opportunities for insurance providers. The remainder of the chapter is structured as follows. Section 4.4.2, which starts with an overview of the most important contributions on the matter from academics, researchers, regulatory and supervisory authorities and operators, aims to provide a complete and exhaustive definition of the concept of microinsurance. Section 4.4.3 considers the demand and supply dynamics in the microinsurance sector. Section 4.4.4 describes the main microinsurance products and their distribution channels. Section 4.4.5 examines strengths and criticalities related to the potential application of microinsurance solutions to more "advanced" contexts. Finally, Section 4.4.6 wraps up our study.

\subsubsection{Microinsurance: definition, literature and regulatory profiles}

In recent years, the microfinance movement has grown more and more demand-oriented and diversified its offer by introducing new product lines, such as savings and insurance products, mostly catering to lowincome groups (Arun and Bendig, 2010, p. 2). Like some traditional insurance products, microinsurance is suitable to cover different risks, such as life, health, farming and property. The prefix "micro-" is normally added to specify that this type of insurance targets poor segments of the population, usually residing in developing countries. Given the specificity of target groups, limited benefit packages are made available in order to keep premiums affordable; in other words, micropremiums are paid for microcoverage (Radermacher and Brinkmann, 2011, p. 64). The very expression "microinsurance" echoes the wellknown microcredit phenomenon. Both, in fact, have a specific focus on low-income households in the developing world. Moreover, they were designed to tackle a number of market imperfections that are deemed to perpetuate poverty. The concept of microinsurance, though, proves to be even more complex than microcredit. Firstly, because it implies the payment of a regular premium against an uncertain payout. Secondly, it 
is mostly conceived as individual contracts, where some parties benefit from compensation while others do not. Finally, microinsurance is far from being homogeneous, as it includes a wide variety of risks and takes a lot of different forms (De Bock and Gelade, 2012, p. 2).

Microinsurance is widely debated by academics, multinational organisations, national governments, public institutions, financial intermediaries, sector operators, non-governmental organisations (NGOs), and the like. Its analysis covers different areas, from the examination of operational solutions aimed at starting and/or developing microinsurance programmes (Churchill, 2007) to the acknowledgment of the prominent role played by microinsurance in providing, along with other microfinance products and solutions, complete management solutions for different types of risks faced by individuals and companies alike (Arun and Bendig, 2010), up to the analysis of the ethical objectives pursued by such initiatives (Radermacher and Brinkmann, 2011). However, while taking into consideration a variety of aspects, including, in particular, regulatory issues (Biener et al., 2014; IAIS, 2007, 2010, 2012; Chatterjee, 2012), demand/supply dynamics (Eling et al., 2014; Liu et al., 2013; Arun et al., 2012; Dercon et al., 2012; De Bock and Gelade, 2012; Arun and Bendig, 2010; Cohen et al., 2005; Churchill et al., 2003; Churchill, 2002), the distribution channels of microinsurance products and the variety of contractual forms offered (Sheth, 2014; Prashad et al., 2013; Clarke and Dercon, 2009), the common thread that holds together the numerous contributions developed over the years is represented by the fact that all such microinsurance programmes were developed and implemented in developing countries; no traces are found of similar experiences in more "advanced and developed" socioeconomic systems. Since the primary objective of this study is precisely to reduce the "information gap" before addressing the problem of how to apply the aforementioned microinsurance programmes to advanced economies, the first necessary step is to analyse the scope of this particular form of insurance. Of course, any time new activities are started, two types of obstacles usually arise: regulatory barriers and operational issues. Obviously, such need becomes even more compelling when the new activities are suitable to produce effects within the financial markets or in those social or economic areas deemed particularly "sensitive" by national governments and where the priority is the protection of the fundamental rights of the public (Santoboni and Vincioni, 2002, p. 32; Proietti et al., 2006, p. 6). From this perspective, considering that the regulation of any market can either promote or halt its development (Biener et al., 2014, p. 21), the first necessary step involves, then, taking 
a look at the current state of regulation of the microinsurance sector. The first useful reference goes to the provisions of a document jointly prepared by the IAIS (International Association of Insurance Supervisors) and the CGAP Working Group on Microinsurance (CGAP WG MI) in 2007, where, among other things, it is stated that "'micro-insurance' means different things for different supervisors. In most jurisdictions, micro-insurance is not considered as a separate type of insurance and just viewed as insurance available in small sums. This could be cited as one of the reasons for non-development of a separate set of rules for micro-insurance in many jurisdictions. There are many ways in which micro-insurance can be explained, for example:

- risk-pooling instruments for the protection for low-income households;

- insurance with small benefits;

- insurance involving low levels of premium;

- insurance for persons working in the informal economy, etc."18

From this initial definition, a further document prepared by the IAIS in 2012 (which substantially confirms what the 2007 paper already anticipated) defines microinsurance "as insurance that is accessed by low-income population, provided by a variety of different entities, but run in accordance with generally accepted insurance practices (which include the ICPs - Insurance Core Principles). Importantly, this means that the risk insured under a micro-insurance policy is managed based on insurance principles and funded by premiums. Premiums can be privately or publicly funded, or a combination of both. The micro-insurance activity itself should therefore fall within the purview of the relevant domestic insurance supervisor." 19

According to the above statements, there seem to be no apparent obstacles, either from an operational or a regulatory point of view, to implementation of such programmes also in contexts other than those in which they were originally designed and developed, as microinsurance is clearly regarded as an activity that must be run and managed in accordance with the same management and regulatory principles applicable to the traditional insurance business. In addition, no substantial differences from the conventional insurance model are envisaged or highlighted, including with regard to the type of products and clientele targeted by microinsurance (low-income individuals). Table 4.1 highlights the key distinguishing features of microinsurance compared to conventional insurance. 


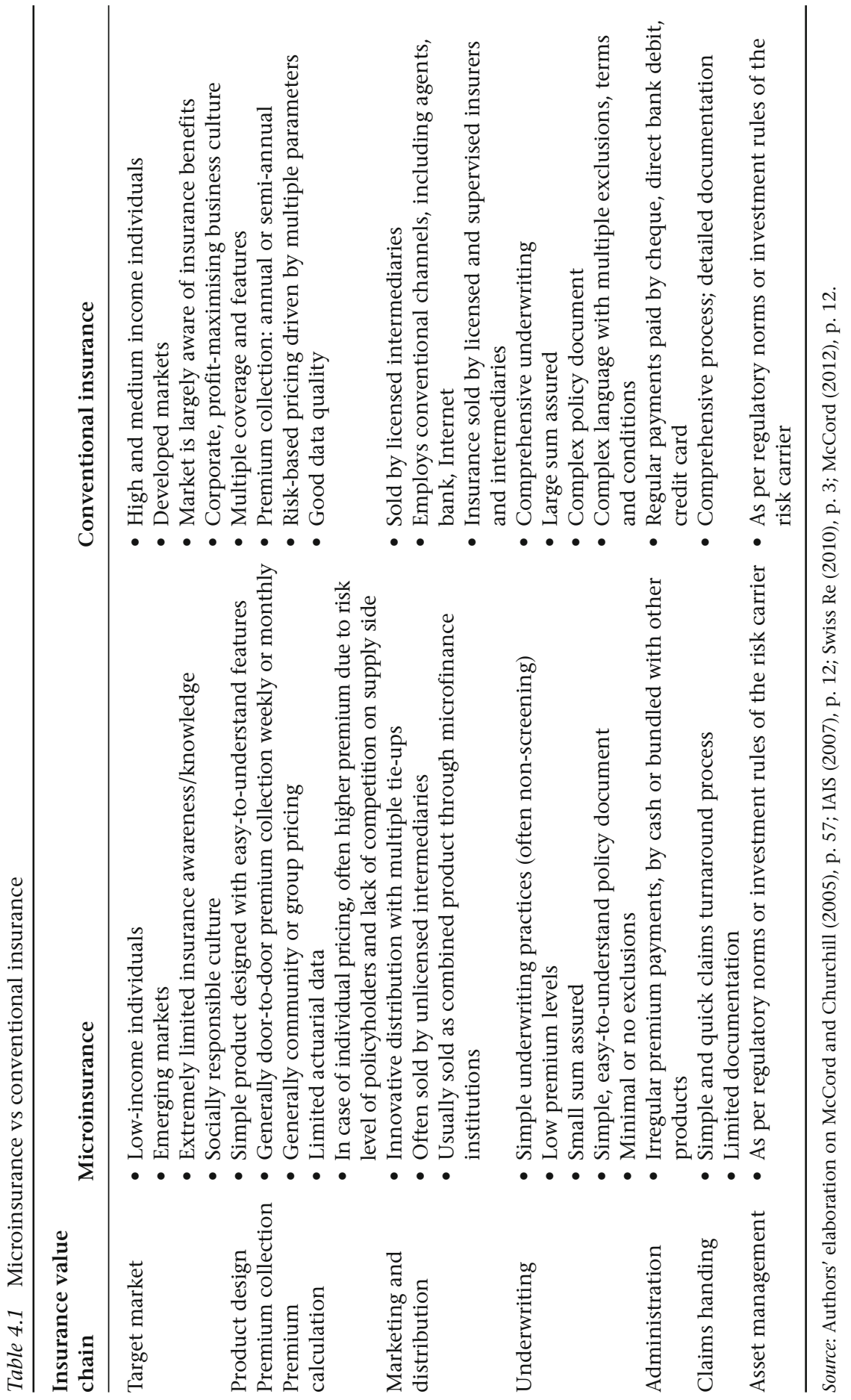


Starting from the above considerations, the following paragraphs try to provide a description of the most important features of microinsurance as well as their potential forms should they be applied to "developed" countries.

\subsubsection{Microinsurance: subjects involved}

\section{Provision of microinsurance}

In order to achieve efficient functioning of the insurance market, a combination of the following should take place: customers and insurance providers need to come together and understand risks and insurance requirements, provide product information, enrol in insurance programs, make payments of premiums, advise, assess and settle claims and deal with other administrative processes in a cost-effective and economically viable way, consistent with market needs (IAIS, 2010, p. 10). From this perspective, insurance undertakings must always identify the best operating solutions, considering the "reciprocal relationship" existing between distribution, customers and insurance services/ products; in other words, the development of any strategy to approach the market must inevitably be based on a consistent relationship between such elements. As expressly provided by the IAIS (2007, p. 24), microinsurance products can be provided by a variety of subjects. Here, in fact, we can identify three different categories of microinsurance providers (Table 4.2):

(a) organisations regulated and licensed under the insurance law (insurers);

(b) organisations regulated and/or licensed under other kinds of law (formal entities under laws other than the insurance law);

(c) informal schemes (entirely unregistered and under no legal setting).

It is clear that only providers of the first type are suitable to provide microinsurance products/services in the more advanced socio-economic systems, as they are subject to specific regulatory provisions that are not applicable to the other two categories.

\subsubsection{Demand for microinsurance}

Generally, individuals, households, and commercial enterprises (in particular, micro and small enterprises) are exposed to a number of risks that can be summarised in the following list, which identifies three main types: pure risk; speculative risk; demographic risk. 
Table 4.2 Insurance providers according to their legal status

\begin{tabular}{|c|c|c|}
\hline $\begin{array}{l}\text { Organisations regulated } \\
\text { and licensed under the } \\
\text { insurance law (insurers) }\end{array}$ & $\begin{array}{l}\text { Organisations regulated } \\
\text { and/or licensed } \\
\text { under any other law } \\
\text { (formal entities under } \\
\text { laws other than the } \\
\text { insurance law) }\end{array}$ & $\begin{array}{l}\text { Informal schemes } \\
\text { (entirely unregistered } \\
\text { and under no legal } \\
\text { setting) }\end{array}$ \\
\hline $\begin{array}{l}\text { - Commercial insurers } \\
\text { (joint stock companies) } \\
\text { - Cooperative or mutual } \\
\text { insurers (member-based) } \\
\text { Some jurisdictions } \\
\text { exempt certain insurers } \\
\text { from being supervised } \\
\text { even though they do } \\
\text { insurance business }\end{array}$ & $\begin{array}{l}\text { - Funeral societies or } \\
\text { associations } \\
\text { - Cooperatives under the } \\
\text { cooperatives authority } \\
\text { - Mutuals under the } \\
\text { mutual authority or } \\
\text { under other laws } \\
\text { - Health insurance } \\
\text { schemes or health } \\
\text { providers under health } \\
\text { authority } \\
\text { - Insurance offered } \\
\text { through post office } \\
\text { under the postal } \\
\text { authority } \\
\text { - Non-governmental } \\
\text { organisations (NGOs) }\end{array}$ & $\begin{array}{l}\text { - Funeral parlours or } \\
\text { unregistered death } \\
\text { benefit associations } \\
\text { - Informal groups } \\
\text { and community } \\
\text { associations }\end{array}$ \\
\hline
\end{tabular}

Source: Authors' elaboration on IAIS data (2007), p. 24.

Pure risk is the possibility of the occurrence of a future unfavourable event of random nature that, if it occurs, may result in damage. On the other hand, speculative risk refers to an uncertain future event that may result in adverse (in terms of loss or damage) or positive (in terms of profit) effects; this category is typical of financial risks. Finally, the definition of demographic risk covers future events related to the human life cycle (in particular, death or survival). Of course, any subject - whether a physical individual or legal entity - is exposed to a variety of risks that represent, so to speak, a "unique" situation that differentiates him or her from other individuals or entities (Santoboni, 2012, p. 11). As most of these subjects often lack proper financial-insurance literacy as well as, more frequently, the economic resources to identify and manage such risks, their needs and requirements in terms of safety can be met through the pooling and transfer of risk offered by insurance services. As a result, access to insurance represents a key issue to facilitate the economic wellbeing, in particular for the benefit of those subjects with limited resources 
available to protect themselves from adversity. At the same time, those subjects lacking proper means may be more exposed to specific vulnerable situations. However, in practice, several markets are characterised by challenges and obstacles that limit access to insurance, particularly for the most vulnerable subjects, including low-income segments of the population and small enterprises (IAIS, 2010, p. 10). These subjects are, de facto, excluded from the "formal" financial markets and generally consist of low-income individuals with irregular income streams, often self-employed or employed in informal enterprises. They are likely to live in high-density urban areas or in remote rural zones that lack proper infrastructures such as roads, markets and access to water and electricity services. They often have low levels of education and financial literacy and in some cases do not even possess a national identity card or certificate of their health status (IAIS, 2007, p. 30).

Considering the typical profile of the excluded subjects in the developing countries, now, conversely, the question is who falls into that category in those countries boasting more advanced economic and financial systems? First of all, they would surely include all those individuals and legal entities that, especially after the economic crisis that started in 2008, fail to access any type of traditional financial and insurance service: the wide pool of immigrants (Magnoni et al., 2010), who now represent a considerable percentage of the population residing in the developed countries; women - such as housewives - willing to start small businesses; unemployed young people having no chance of turning selfemployed or starting their own business (Porretta and Santoboni, 2014); subjects who had problems with drugs or with the law and are willing to start new personal or business careers and, mostly, microentrepreneurs, who play a key role in the development and growth of the economy in several European countries, as they represent their backbone in terms of turnover, generation of wealth and employment. With regard to the last, it should be pointed out that microinsurance represents an undeniable advantage for any enterprise, as it helps outsource business-related risks. Secondly, personal insurance allows entrepreneurs to use microcredit solely for their business. In fact, as highlighted by Hamid et al. (2011), improved health conditions lead to higher productivity and reduced expenditure on health care. If households are insured against health risk, they are likely to invest more in their business because they do not need to hold highly liquid assets for precautionary purposes (Ashta, 2013 , p. 2). From this perspective, the economic growth of these countries is also dependent on the capacity/possibility of microentrepreneurs to exploit potential business opportunities to their fullest, provided 
that they are allowed to access credit and proper insurance coverage (Santoboni and Arcadi, 2011).

\subsubsection{Microinsurance: products and distribution channels}

Microinsurance offers a viable alternative to the traditional insurance system to low-income individuals, households, and commercial enterprises, as it gives them an opportunity to manage their risks (Swiss Re, 2010 , p. 1). In recent years, a number of innovative products have been specifically designed for the developing world (Clarke and Dercon, 2009, p. 6). However, though the array of microinsurance products on offer is wide, in many case they are limited to some forms of life and health microinsurance (IAIS, 2007, p. 17). Like all types of insurance, microinsurance policyholders make regular premium payments proportionate to the likelihood and cost of the risk involved. However, microinsurance is more than a simply downscaled "formal" insurance; it is a type of formal insurance tailored to a clientele with vastly different income and risk profiles than those involved in traditional insurance schemes indeed. To create viable microinsurance programmes requires innovation in designing suitable products and services in terms of coverage, timeliness, accessibility and affordability. Achieving the most appropriate design of such products requires an understanding of both the microinsurance demand and supply dynamics as well as its products, with regard to both formal and informal instruments (Cohen et al., 2005, pp. 319-320).

In order to identify the types of products most in demand in developing countries, we should firstly refer to the types of risks that individuals and legal entities residing in those countries are mostly exposed to. From this perspective, health-related risks naturally represent the biggest source of concern for low-income families and microentrepreneurs, as accidents and disabilities, such as illnesses, may result in high expenditure for medical treatment as well as indirect costs, including income loss. However, other types of risks are worth considering, too, including the following:

- Life-cycle risks: death or permanent disability of household heads or entrepreneurs can further aggravate the poor conditions of their families or enterprises. In addition, many low-income households and microenterprises appear also ill equipped to face major life cycle events such as old-age and retirement.

- Financial risks: such as crop spoilage, lower market prices for products, death of livestock or loss of business assets may significantly impact the earnings of low-income families and microenterprises. 
- Disaster-related risks: events such as earthquakes, tsunamis, storms and floods may result not just in a great deal of human losses but also in relevant damages to property, assets and economic activities that affect the livelihood of low-income individuals (Swiss Re, 2010, p. 4).

Several microinsurance products and instruments are available to tackle and manage such types of risks faced by low-income subjects, whose scope and range is almost as varied as that provided by the so-called commercial insurance system. Microinsurance can be offered as a singlerisk product, or several types of coverage can be bundled into composite products, including instruments underwritten by different risk carriers (Churchill, 2007, p. 402). However, in normal business practice the products most in demand are:

- credit life insurance: these policies are generally combined with other microcredit products allowing subjects to regularly pay their creditors not only in the event of death or injury, which prevent them from generating income, but also in case of job loss;

- health insurance: these policies offer protection to individuals against

(a) events that cause objectively discernible injuries, resulting in death, permanent or temporary disabilities;

(b) situations of need arising from illness, such as the necessity to undergo medical treatment or surgery or, generally, any situation where the insurers need to access health-care services;

- funeral insurance: an insurance policy where the benefit is used to cover funeral expenses; the benefit can be in the form of a funeral service, a cash benefit that can be used to help pay for a funeral, or a combination of the two (Hougaard and Chamberlain, 2012, p. 217);

- assets insurance: these policies allow protecting the assets of households or entrepreneurs (e.g., homes, business assets and so on);

- agriculture insurance: as microinsurance was initially created and developed mostly in rural contexts where agriculture represents one of the main activities, this kind of policy protects households and microentrepreneurs against a variety of events (mainly climate-related) that may affect their yearly crops and jeopardise the profits from agricultural activity.

Here it is clear that were microinsurance solutions to be implemented in the economies of the developed countries, theoretically all the above 
types of insurance policies would be applicable and marketable in their own reference markets. First of all, liability insurance policies, health insurance policies, accident insurance policies, not to mention funerary expenses policies, could be particularly useful for immigrants, including immigrants engaged in entrepreneurship.

Moreover, some insurance policies, defined as eligible guarantees (unfunded ones) by the Basel Committee in the Credit Risk Mitigation rules, can be used to reduce the banks' capital requirements and, consequently, facilitate access to credit for the applicants. Then there are other policies that do not "make life easier" for the banks in terms of recovering their credit but help by considerably reducing the risk of default by enterprises (or microenterprises); they would be worthy of greater consideration to assess and determine creditworthiness, allowing thus access to credit in more advantageous terms and conditions for the applicants. Whereas in "developing countries" we have women working on their weaving looms, which represent the necessary tools of their trade, in "developed" countries microentrepreneurs may rely on machinery to carry out their work and, therefore, generate profits. If the machinery breaks down, such profits obviously cannot be generated any more and, theoretically, also their capacity to return the credit obtained is halted. Hence, proper insurance coverage could help these subjects achieve their objectives in terms of loan repayments. In particular, loans can be supported by specific products, such as credit protection insurance policies (CPI); this, without omitting the importance of other types of insurance contracts, which, de facto, reduce the general risk profile of the subjects insured; the latter include liability insurance policies, so-called business interruption policies, etc. These are all tailor-made instruments designed for the needs and risks associated with the enterprises according to their areas and sectors of activity. As for the distribution channels, microinsurance products can be marketed to their target clientele in different ways. Here too, we should distinguish between "developing" and "developed" countries. In the former, customers often live geographically far from where insurance services are available and may migrate seasonally in search of work. For this reason, sales and servicing result very challenging. Access to microinsurance products, therefore, can be achieved through different distribution channels: "traditional" channels (agents and brokers), banks, microfinance institutions (MFIs), non-government institutions, direct marketing (e.g., call centres), direct mail (e.g., mail lists purchased from other mass-service providers), retailers (e.g., supermarkets, clothing stores, pawnshops, furniture and electronic goods stores and corner shops), alternative 
direct sales entities (e.g., electricity, gas, landlines and mobile telecommunications companies) and technology-based distribution (e.g., mobile phones and Internet providers; see Smith et al., 2011; Prashad, 2013). Delivery could also be supported via community-based schemes or groups and credit unions, as well as innovative mass-based distributors such as retail shops, post office outlets, religious associations and trade unions. Not only are these alternative outlets potentially bound to overcome geographic barriers, but they also have the capacity to reach customers in a more cost-effective fashion, leveraging on infrastructure and overcoming issues of mistrust (IAIS, 2012, p. 10). Looking at the "developed" countries instead, as the supply of microinsurance products must necessarily follow the regulatory framework designed to govern the "conventional" insurance sector, it is clear that microinsurance policies can be distributed only by the aforementioned regulated subjects; namely only those expressly recognised by the reference legislation: agents, brokers, banks and other authorised insurance intermediaries and direct sales (including phone and online sales).

\subsubsection{Microinsurance in the developed countries: strengths and weaknesses}

In some contexts, conventional insurance services are oriented to serve some areas of the market but look poorly equipped to cater to other customers, such as workers operating in the informal sector, those characterised by highly variable and unreliable income and those with particularly low income or segments of the population who see conventional insurance as only for wealthy people (IAIS, 2010, p. 11). From this perspective, it appears that development of microinsurance solutions could represent a key risk management solution for this pool of subjects in demand for insurance and whose needs are not met by the traditional/conventional insurance circuit. However, prior to experimenting with new initiatives, it is imperative to perform a preventive analysis of the costs and benefits associated with them. In this sense, considering that an increasing number of insurance providers based in developed countries are trying to penetrate new markets in developing countries through specific microinsurance products and channels, what could be the advantages and disadvantages of starting microinsurance programmes and initiatives also in more advanced economies?

As for the strengths, the following are identified:

- Use of the same target clientele of microcredit and/or microfinance programmes. Basically, since the potential recipients of microinsurance 
and microfinance products are the same, microinsurance policies could enjoy particular advantages during the placement phase.

- Limited amount of premiums: generally, premiums paid against the signing of microinsurance policies are of modest size and, therefore, affordable also by subjects who are generally excluded from the "conventional" insurance system.

- Reduction of risk of default of the insured subjects: as these subjects are exposed to risk to a lesser degree, they are also likely to be better equipped to face adverse events that may affect their personal life and/or business. As already seen, such circumstance should lead to improved conditions to access credit.

- Possibility to check up risk profiles and provide assistance in planning insurance needs: customers entering insurance/microinsurance policies should also benefit from "insurance risk management" services. In other words, the subjects selling the microinsurance products should go beyond their role of providers, offering also assistance and advice services to individuals and microentrepreneurs alike.

- Promoting and raising awareness of potential risk areas to which subjects are exposed: this aspect is strictly related to the previous bullet point, as the possibility of enjoying a check-up service on potential risks generally allows customers to improve the planning of their insurance needs and, consequently, make the most appropriate choices according to their risk profile.

- High "social" return for all subjects involved: the dissemination of microinsurance solutions could result in positive effects for all stakeholders (customers and providers; the general public, the numerous public actors, such as governments, policymakers, regulators/supervisors; etc.) involved in this sector.

- Presence of partial/total incentives to enter into such contracts: possible public contributions/subsidies for the payment of the premiums, provided by central and/or local government authorities; this aspect could be the key to trigger the full-scale development of this insurance model also in developed countries.

In particular, with regard to the last considerations, it must be pointed out that in several countries where microinsurance is widespread, the state - as the risk manager of last resort and guarantor of a basic level of social protection for all - may determinate that there is a need to sponsor access to microinsurance for the benefit of the most underprivileged subjects through redistributive practices. From this 
perspective, it is possible to identify three different ways for funding microinsurance:

(a) premiums may be fully paid by the policyholders (privately funded);

(b) premiums may be partially paid by the state (hybrid schemes and publicly funded);

(c) premiums may be paid by other components of the community, such as formal sector employers (cross-subsidies through the contributions paid to statutory social security schemes).

Since some microinsurance risks are, by their nature, social security-oriented, governments should determine the scope and level of a minimum guaranteed package of social security for all and organise access to it through legislative and regulatory means. Microinsurance could then be used by national governments to deliver this social protection package and thereby extend social security to uncovered segments of the population (IAIS, 2007, pp. 14-15).

While these are the undeniable strengths associated with microinsurance, conversely, the presence of several weak points cannot go unmentioned:

- provision of limited guarantees: of course, limited premium amounts can only go hand by hand with limited insurance coverage;

- need of reaching a critical threshold of the insurance pool, both for technical and economic reasons (profit): this critical element is connected with:

(a) lack of technical data to determine the tariffs: from an operational standpoint, this is probably the greatest obstacle that might discourage insurance providers from entering the microinsurance market; companies should, therefore, resort to alternative methods to assess the risk profiles of microinsurance clients: from this perspective, a number of data should combined and shared (in order to determine "reasonable" tariffs) by all subjects involved during the start-up phase of the microinsurance programmes;

(b) low economic returns from individual products: the fact that every policy is associated with a premium of limited amount often discourages potential microinsurance providers from entering this market; 
- low levels of financial/social security/insurance literacy: the desired population target is, in most cases, characterised by poor knowledge of the risks to which individuals and/or microentrepreneurs are exposed; this circumstance often affects the choice of the most suitable products/solutions for the timely management of said risks;

- a reduced default rate related to insurance policies still does not translate, from an operational point of view, to improved conditions to access credit; however, as we have already seen, the practice has highlighted a number of synergic efforts characterised by the combination of microfinance products backed and/or supported by microinsurance policies (Santoboni et al., 2012a, 2012b); as a confirmation of this, the IAIS itself (2007) duly stressed that any time microinsurance customers were able to access microcredit, they proved to be reliable borrowers and were generally able to honour their obligations.

\subsubsection{Some conclusions on microinsurance}

The economic crisis that has gripped the developed countries in recent years has contributed to exacerbating a number of chronic issues that have long characterised their social and economic systems, in particular those related to the gap between a limited number of wealthy individuals and growing sectors of the population that struggle to make ends meet and fail to secure a minimum level of subsistence. From this perspective, with an eye on a number of some consolidated microfinance and microcredit experiences, this study represents a first attempt to affirm microinsurance not simply as a phenomenon catering exclusively to the most vulnerable strata (or the totality, in some cases) of the population, often far away (not only geographically) from the "developed" countries, but also as an "alternative" form of providing insurance services, which, following proper operational and regulatory adjustments, could be applied also to advanced economies in order to meet the demand and needs of those subjects traditionally excluded from the "conventional" insurance circuit. Obviously, several obstacles may hinder the full-scale development of this new model of providing insurance. As already mentioned, first of all there are regulatory obstacles, which may considerably prevent potential microinsurance providers from entering this market; to this must be added operational hurdles, including strictly technical problems (e.g., the creation of pools of insurers allowing for an effective management of the risks undertaken) as well as strategic issues (assessing, e.g., the opportunity - besides the mere economic convenience - of entering the microinsurance business), commercial (e.g., the 
selection of products and distribution channels) and organisational issues. Yet although aware of the existence of the above obstacles, the authors believe that interrupting an already started trend and moving backwards would definitely lead to giving up all the undeniable "social" returns as well as the other advantages offered by microinsurance - for the benefit of all the stakeholders involved, on both the demand and supply sides.

\subsection{Social housing: introduction and the Capacity Building project issues}

\subsubsection{New developments of housing policies in the European Union}

The European Parliament Resolution of 11 June 2013 on Social Housing in the European Union (2012/2293(INI)) is the reference document establishing the foundations for a new strategic plan for the housing policies of EU member states. ${ }^{20}$ This plan aims to integrate the existing national policies on the matter by establishing a common quality framework, which should include:

- policies for equal social housing opportunities;

- social inclusion policies;

- policies for the promotion of citizenship and non-discrimination;

- local development policies.

According to the resolution, access to decent and adequate housing is one of the fundamental rights of EU citizens and represents a key tool to achieve justice and social cohesion. From this point of view, investment in affordable housing is a precondition for enhanced labour mobility ${ }^{21}$ and increased employment opportunities, in an effort to meet the growing demand for affordable homes of ample segments of the EU population who struggle to cope with the severe economic crisis that continues to entangle the whole continent with its harshly negative effects. A social housing policy is an integral part of services of general economic interest by helping to meet housing needs, facilitate access to property, improve existing living space and adapt housing to the family situation and resources of the occupiers. More and more people are being affected by the current economic and social crisis; for many of them access to housing represents the minimum prerequisite to access citizenship rights. Specifically, we refer here to young people, 
multi-individual families, students and young people starting their careers, young unemployed couples and people with disabilities. Among the most vulnerable categories are single-female-adult-headed families with children, women with low incomes, women with poorly paid jobs, migrant women, widows with dependent children and women who are victims of domestic violence. Relying only, as has often been the case in recent years, on a combination of market forces and financial austerity measures to rebalance such a critical picture is likely to aggravate a situation which is already spinning out of control. Moreover, cuts in housing benefits and social services, the growing taxation of social housing providers and the selling off of parts of national social housing stocks have all contributed to fragmentation and weakening of housing schemes aimed at promoting fair, equal and social housing, for in many countries their weight is minimal. The financial crisis and the persistent and recurrent property bubbles have further tightened the conditions for accessing the housing market, hitting hard, and mostly, at the middle class, especially in those European countries, like Italy, where the number of government-owned residential and social housing units is low and, conversely, there is a high percentage (over 70 per cent) of firsthome owners. An increase in the number of forced evictions ${ }^{22}$ and the persistent reluctance of the local banks to step in a socially responsible manner to provide financial support to growing sectors of the society for their housing needs is currently putting a strain on governments struggling to find adequate and, mostly, long-lasting solutions to the issue. The European Parliament, therefore, calls on all member states, through its resolution, to take action and increase the consistency and integration of financial instruments used in the past and develop new financial tools in order to tackle this serious situation. Innovative, multilevel housing policies are called upon to harmonise and integrate national policies on different levels and areas of intervention, including state aid, structural funds, policies for savings and energy-efficiency improvement, fight against poverty and social exclusion, health-care policies.

In this perspective, the aforementioned act encourages tenants, landlords and their most representative associations to actively participate in defining housing strategies, calling for their involvement in the decision-making process. In addition, the following are encouraged:

- use of the structural fund resources to support energy efficiency and renewable energy projects in social housing, which must be affordable, as well as sustainable and integrated urban development projects; 
- new integrated development instruments ("community-led local development" and integrated territorial investments) are needed for the promotion of strategies to support residential housing, where social housing providers, authorities ${ }^{23}$ and tenants can play an essential role;

- innovative use of the resources provided by the European Social Fund (ESF) to invest in training, creation of jobs and professional requalification, in particular for those "green" professions, such as those related to replacement and/or reconversion of heating systems in buildings.

Finally, the following aspects are stressed:

- potential advantages originating from incentives to be used for the installation of energy-efficiency systems and the generation of renewable microenergy in social housing; ${ }^{24}$

- the advantages of the fight against energy poverty (reduction of domestic energy consumption for heating due to high costs, deterioration of living conditions in the buildings, etc.) related to the health of occupiers (e.g., respiratory and cardiovascular diseases, allergies, asthma, carbon monoxide intoxication, mental illness).

In short, the aforementioned resolution incorporates and properly outlines a number of guidelines on social policies in Europe, sheds light on some important future developments and, mostly, pushes for increased integration between policies, programmes, stakeholders and financial instruments; integration is actually regarded as the key aspect to ensure the efficacy of these measures. That being said, policy integration at a European level is undermined by the variety of different national housing policies, which are characterised by specific connotations and peculiarities, starting from the different welfare systems in place in each country. Generally, the consistency of social housing, that is, housing dedicated to the weakest segments of the population, can be measured by looking at the percentage of social rented houses owned and managed by the state on the total rental housing. ${ }^{25}$ Also, there is little doubt that the new policies emerging from the economic crisis are characterised by a strong use of public resources for social housing. They instead show a preference for programmes and interventions where public actors assume the role of activator, promoter and partner of public-private partnerships and the last-resort supporter of 
measures aimed at mitigating the risk of losing access to decent and adequate housing.

\subsubsection{Social housing and housing microfinance}

In these paragraphs we analyse the peculiarities of another instrument of microfinance: social housing. Although not expressly mentioned in the aforementioned EU resolution, the set of actions supporting the provision of buildings for social purposes is commonly called social housing. ${ }^{26}$ However, it is not easy to formulate a univocal definition ${ }^{27}$ of this expression, and this is also the reason why, in our opinion, no specific reference can be found in the above resolution. In a nutshell, the following are common features of social housing in the EU member countries:

- the concept of general interest intrinsically connected to social housing schemes;

- the objective of increasing the supply of affordable homes for a number of target beneficiaries;

- relative vulnerability of the target subjects.

Apart from these common factors, the different national systems show no significant homogeneity in methods of access to (1) housing, (2) construction land ownership, (3) rental systems, (4) methods to access finance for the target population. This makes the national experiences extremely different from one another and characterised by different general performances and a mix of instruments in place. With regard to its most widespread forms of social housing, the expression may basically refer to two different types of interventions.

The first type includes activities carried out by public and private actors and generally refers to subsidised housing related to assistance to alleviate the payment of interests for the purchase of real estate property, tax incentives, supplements or special grants for long-term acquisition of land ownership and implementation of low-cost public services. The second type, the more traditional, refers to housing tenure owned and managed by the state, which, through incentives and other forms of aid, builds directly a number of social rent homes, homes built by cooperative providers or through a combination of public/private partnerships. ${ }^{28}$ Both concepts are characterised by the absence of forprofit actions and the possibility of long-term rents in order to recover investment as well as operational costs for ordinary and extraordinary maintenance. 
According to these definitions, the following fall under the category of social housing:

- houses built thanks to support and intervention of the state that today are deteriorated and need maintenance and/or restoration in order to improve the quality of both living spaces and their energy performance; most of them are state-owned;

- houses built by private or public-private partnerships with highly diversified levels as for types, products and forms of ownership; ${ }^{29}$ this housing group too is often in bad need of refurbishment/retrofit. In these cases, most interventions tend to focus especially on energy efficiency of buildings and/or houses, as it is one of the main factors driving up costs.

In light of the foregoing, there is no doubt that social housing is a useful tool, albeit not the only one, to address the above issues and include that set of interventions that go by the name of housing policies. Housing policies promoting social inclusion, in fact, are not limited to the supply of adequate and affordable housing to low-income individuals at risk of poverty and/or social exclusion, although such interventions are fully justified and needed. In recent years, housing policies developed in different European countries, in fact, have combined social housing interventions with a variety of ordinary measures at various levels, including the following:

- measures to facilitate access to credit for the purchase of homes at subsidised costs;

- self-construction and small maintenance interventions to improve quality of housing;

- measures to support the payment of arrears for people struggling with their housing costs and/or at risk of eviction;

- supplements to meet domestic energy cost or rents for temporary homes for a limited period of time for homeless families;

- measures to improve habitability and safety of houses occupied by elderly and disabled people (home automation);

- measures for the supply of temporary dwellings for the homeless.

The above measures are urgently needed and justified also in light of the following:

- the gravity of the current economic crisis and the fact that access to decent housing is considered one of the fundamental rights under the EU rights, equality and citizenship programme; 
- a worrisome increase in the number of potential recipients of housing measures, including middle class, which are at risk of poverty and/or losing the full use of their dwellings;

- strongly diversified and fragmented target groups, each one carrying issues related both to the need for decent and adequate housing and lack of subsistence income (of which rent is often the largest portion);

- continuous and growing situations where poor housing conditions are worsened by a reduction of domestic energy consumption, which call for measures to support and improve the health of tenants;

- strong correlation between urban regeneration policies, housing needs and policies aimed at improving urban energy performance as a basis for local development and the creation of a new model of "urban living".

In light of such premises and given the extreme variability and extent of the demand for affordable housing as a primary citizenship right, today housing policies in the EU member states tend to be divided into:

- preventive policies, characterised by measures and interventions preventing the risk of losing housing. These economic support measures prevent the beneficiaries from entering circuits of real economic hardship and poverty as well as the relevant social risks (eviction, decay, diseases, social isolation);

- policies for repairing and improving, characterised by interventions aimed at increasing the quality of living spaces and restoring standard living conditions, thus reducing the existing housing problems. ${ }^{30}$ This group includes those interventions that improve energy performance and the provision of basic services and utilities, both for single houses or entire buildings;

- expansive policies, characterised by long-lasting interventions promoted by the state and private subjects (including public-private partnerships) aiming at increasing the supply of social housing (with subsidised costs and rents);

- inclusive policies, focusing on particularly vulnerable subjects (elderly, disabled, single mother supporting children, immigrants, young couples, Roma, etc.). ${ }^{31}$

These categories can help us identify some of the possible features of the interventions as well as the main differences between the instruments currently in use. In any case, they are not meant to set any interpretative 
limits. Actually, they should be regarded as opportunities to introduce innovative measures that may lead to integrated and modular interventions relying on instruments characterised by greater flexibility and customisation. Such instruments are currently being introduced by social housing policies and for social inclusion purposes, as they enrich and complement each other.

In fact, in light of the persistent economic crisis and a consolidated trend where the state and local government administrations are consistently reducing social housing measures, ${ }^{32}$ the issue of social housing cannot be effectively addressed and solved only through the use of long-term and expansive instruments. On the contrary, short-term measures are definitely needed to tackle and combat social exclusion and create conditions to maintain long-term ownership and full habitability of dwellings, for the benefit of a wide spectrum of beneficiaries who struggle to cope with rising housing costs. This picture, therefore, calls for systematic use of forms of assistance, to be negotiated between public and private actors, that focus on reuse, improvement of living spaces and energy performance in buildings in an effort to mitigate the risk of losing houses due to occupants' low income. In particular, these short- to medium-term policies aimed at social inclusion:

- coverage of financial needs of individuals (for purchase, refurbishment, energy efficiency, maintenance and habitability of houses) supported by guarantees provided by public entities to the financial intermediaries;

- state aid measures (also in partnership with private subjects) for the improvement of urban living conditions through the use of certain financial opportunities and instruments at a local, regional, national and European level (e.g., national and regional plans, European Social Fund, European Regional Development Fund).

represent, in general, two aspects to be considered to effectively promote housing investments in the next two years of the programming period. As for long-term policies, in particular those termed expansion policies, we believe that governments need to carefully assess the options at stake, also in light of future developments of the current economic crisis, which is likely to significantly drive and shape the political agenda. Anyway, what instruments are available to facilitate development of interventions to support broader and more articulated housing policies aiming at social inclusion? 
Elsewhere in this volume, we have closely analysed a number of measures designed to promote social inclusion and local economic and social development through the activation of forms of assistance for disadvantaged subjects. Most European experiences described in so far revolve around the use of microfinance instruments and, in particular, microcredit through the creation of guarantee funds or European programmes, such as Progress or JEREMIE, to support enterprises; also, in collaboration with qualified national and European financial intermediaries. However, in addition to microcredit for enterprises, other forms of support are spreading thanks to the use of financial instruments such as microinsurance, microleasing and microcredit, dedicated to some categories of disadvantaged beneficiaries (tenants and small landlords) within the aforementioned housing policies. This is an innovative approach, which finds its historical references, just like in the case of microcredit to support enterprises, in programmes already tested in various developing countries around the world under the name of housing microfinance. The typical housing microfinance schemes of the last 30 years $^{33}$ provided financial support to instruments directly implemented and managed by households and/or specific target groups with the assistance of financial providers (non-financial services) and according to their living standards. Such measures consisted in the construction of buildings or part of them, modification of living spaces through improvements of their habitability, control and development of urban areas characterised by rapid and forced urbanisation or reconstruction of housing stock hit by wars and/or natural disasters. ${ }^{34}$ Typical examples would be the expansion of floor space due to new households' needs (birth of new children), improvement of toilets or the general quality of dwellings (statics, structure, minimal safety conditions, etc.). These interventions were made possible by:

- the presence of free skills to the household that can support the selfbuilder;

- the possibility of using/acquiring low-cost expertise at the local level;

- the technical characteristics of the interventions, which generally do not entail strong technology criticalities;

- the substantial absence of stringent general housing regulations;

- the implementation of interventions in low-density rural and/or urban areas.

The microfinance instruments already developed in the late 1990s by global financial institutions and banks met the needs and requirements 
of a number of recipients in a flexible, effective and efficient manner by strengthening the use of housing microfinance in several geographic areas worldwide through the provision of specific financial services targeting specific categories of beneficiaries with limited financial means or at risk of poverty. These experiences, which include a variety of situations and phenomena that cannot always be included under the aforementioned types, share the trait of support being provided to improve living and housing conditions in developing countries, often within broader financial and aid programmes aimed at improving and developing the economies and societies of entire geographic areas. Such developments were also made possible thanks to the resources provided by specialised financial entities and organisations, including NGOs. Although it is hard to automatically transfer such experiences to the European context and, more specifically, to EU member countries, given the strong peculiarities of the developing countries where they were first applied, these schemes, with a few exceptions characterised by excessively "pauperist" connotations in countries where such experiences were first consolidated, have shown the strength, versatility and effectiveness of microfinance products applied to general housing. ${ }^{35}$

\subsubsection{The Capacity Building project. Social microcredit to support local housing policies: new instruments for social inclusion}

The Capacity Building project is trying to identifying, in a testing phase (types of recipients, types of interventions to be financed, repayment methods, types of financiers), innovative instruments and schemes to support housing policies. It seems possible to successfully implement these interventions also in urban and metropolitan areas, starting from a clear definition of the objectives in terms of social inclusion of the beneficiaries. The pilot project launched through the Capacity Building project, implemented in Italy by the National Microcredit Authority, proposed a reconfiguration of the existing housing microfinance tools. The instrument chosen is the social microcredit, ${ }^{36}$ in accordance with the national legislation and supporting the social and housing inclusion of the recipients, within broader innovative policies for social housing ${ }^{37}$ that are currently being activated. Such instruments are naturally integrated with other tools characterised by a broader scope, such as those financed by the EU structural funds to promote energy efficiency of buildings and urban regeneration, ${ }^{38}$ as well as those funded by the national funds under the house plan approved in $2014 .{ }^{39}$ As already highlighted, the Capacity Building project aims to boost the 
administrative expertise of the Italian regions already involved in the former programme Objective Convergence. Regional administrations receive training to develop organisational skills aimed at improving their use of innovative financial engineering instruments. The instrument used for this kind of intervention is social microcredit, ${ }^{40}$ that is, financing in the form of personal loans supported by a public guarantee fund, which according to certain eligibility requirements of the recipients and specific repayment terms and conditions, may allow some categories of vulnerable subjects to cope with sudden housing conditions that may, if not appropriately addressed and solved, lead to poor living conditions and social exclusion.

Below is a summary of the main characteristics of the project on housing (Table 4.3).

The Capacity Building project includes also support to a number of specific operational activities summarised by the table below (Table 4.4).

The diversity and complexity of the various forms of intervention under this platform are the result of in-depth discussion which involved the main stakeholders of social housing policies at national and local level, such as regional administrations and municipalities of the largest metropolitan areas in the regions involved in the project, the main

Table 4.3 Capacity Building project: main characteristics for housing

\begin{tabular}{ll}
\hline Purpose of the & Provide funds, through social microcredit supported by \\
intervention & guarantee funds, for interventions aimed at improving \\
& housing conditions in order to facilitate social inclusion \\
& of disadvantaged individuals in metropolitan areas \\
Specific objectives & Promote urban regeneration, that is, limited \\
& refurbishments aimed at improving quality of living \\
& spaces and energy efficiency of buildings \\
- & Facilitate the provision of loans for landlords and \\
& tenants in order to prevent risk of social exclusion \\
End beneficiaries & Homeowners gripped by poor housing conditions and \\
& social and economic instability \\
- & Tenants of private and public housing in poor housing \\
& conditions and social and economic instability \\
Financial & Guarantee fund created by regions (or municipalities) \\
instrument & to support social microcredit (max. €10,000) provided \\
& by banks affiliated with the public entities (regions, \\
& municipalities)
\end{tabular}

Source: Authors' elaboration. 
Table 4.4 Operational proposals of the Capacity Building project

\begin{tabular}{|c|c|}
\hline Recip & n be dire \\
\hline $\begin{array}{l}\text { Homeowners in } \\
\text { poor material, } \\
\text { social and } \\
\text { economic } \\
\text { conditions }^{a}\end{array}$ & $\begin{array}{l}\text { - Payment of a (limited) number of mortgage rates to } \\
\text { prevent risk of insolvency for the creditor banks } \\
\text { - Small refurbishment work of properties needed to } \\
\text { ensure decent hygienic and sanitary conditions for the } \\
\text { habitability of houses } \\
\text { - Expenditure for retrofitting of electric, plumbing, heating } \\
\text { systems, etc. } \\
\text { - Improvement of energy efficiency in houses/buildings } \\
\text { (replacement of doors and windows, installation of } \\
\text { photovoltaic systems, etc.) } \\
\text { - Building renovation } \\
\text { - Interventions to remove asbestos from old, privately } \\
\text { owned residential and commercial buildings }\end{array}$ \\
\hline $\begin{array}{l}\text { Tenants in } \\
\text { poor economic } \\
\text { and social } \\
\text { conditions }^{b}\end{array}$ & $\begin{array}{l}\text { - Payment of a limited number of rent arrears to avoid } \\
\text { eviction } \\
\text { - Coverage of the costs arising from damages caused by tenants } \\
\text { - Coverage of defaulted monthly instalments } \\
\text { - Refurbishment work agreed with property owners, to be } \\
\text { deducted from the rents accordingly } \\
\text { - Advances on safety deposits to rent of new apartments } \\
\text { to avoid eviction and/or advance payments of the first } \\
\text { monthly rents } \\
\text { - Support to the payment of rent for temporary housing (max. } \\
18 \text { months) in case of eviction while awaiting new housing }\end{array}$ \\
\hline $\begin{array}{l}\text { Tenants of } \\
\text { private and } \\
\text { public housing } \\
\text { in poor } \\
\text { economic and } \\
\text { social conditions }\end{array}$ & $\begin{array}{l}\text { - Payment of a limited number of rent arrears to avoid eviction } \\
\text { - Support to the payment of rent for temporary housing } \\
\text { (max. } 18 \text { months) in case of eviction while awaiting new } \\
\text { housing } \\
\text { - Advances on safety deposits to rent new apartments to avoid } \\
\text { eviction and/or advance payments of the first monthly rents }\end{array}$ \\
\hline
\end{tabular}

${ }^{a}$ Conditions and terms to access the benefits will be outlined later.

${ }^{b}$ Supporting the rights of private property owners who rented their property or are willing to do so under the agreed rental scheme.

Source: Authors' elaboration.

cooperative organisations that do not own or manage public housing stock $^{41}$ (Federcasa), non-profit organisations (Lega Cooperative Abitanti, ${ }^{42}$ Federabitazioni) and the most representative tenant associations (SUNIA $)^{43}$ and small homeowners' organisations (UPPI). ${ }^{44}$ To these must be added a number of technical partners who train operators and provide adequate technological expertise, such as various architect associations, 
the National Board of Architects and national technical partners, such as Casa Clima, specialising in energy-efficiency work. As for the financial operators, the project involves commercial banks and the network of microcredit operators already involved in previous activities aimed at developing microcredit programmes to support enterprises. This platform is being discussed and examined in order to activate pilot projects within the programming period $2014-2020$ as soon as possible.

\subsubsection{Possible developments within the programming period 2014-2020: the Italian case}

In Italy, the Ministry of Infrastructures and Transport, through its directorate-general for housing policies, is working to promote a national programme which should promote a policy to harmonise opportunities offered through the Italia partnership agreement and its thematic objectives. This is the national plan for residential housing, in process of being finalised, whose objectives are as follows:

- to reduce housing problems;

- to maximise use of buildings;

- to ensure safety of buildings;

- to reduce building energy consumption and management costs;

- to regenerate urban spaces;

- to prevent social insecurity and disintegration;

- to facilitate the development of cohesive communities and solidarity among residents.

The plan aims to intervene, within a series of opportunities offered by the thematic objectives of the partnership agreements, by providing for adequate synergies with other interested ministries (Ministry of Economy, Ministry of Labour, Ministry of Health). Besides thematic objectives $4^{45}$ and $5,{ }^{46}$ within the broader framework to support technological innovation under thematic objective 1 , such interventions shall focus on implementation of the provisions under thematic objective 9, Social inclusion and fight against poverty (promote social inclusion, fight any form of poverty and discrimination). More specifically, this thematic objective provides for the activation of a number of measures within the housing policy that target the weakest segments of the population. Such interventions intend to:

- build social housing for social inclusion purposes dedicated to specific targets: immigrants and refugees, individuals in emergency conditions due to eviction or family issues, etc. (ERDF, ESF); 
- build social housing provided with shared facilities; for instance, dedicated to elderly or single mothers with dependent children $(E R D F, E S F)$;

- develop housing solutions within an integration plan between social and health-care services and generally dedicated to independent living (housing lead) (ERDF, ESF);

- create or strengthen networks for housing policies, social services, health and employment services between local government authorities and also with private entities engaged in the provision of measures to fight marginalisation, in particular with regard to non-profit entities. (ESF);

- implement promotional services to support assisted housing within the pilot project aimed at experimenting innovative housing and social models, targeting the needs and requirements of specific target subjects;

- promote measures to support costs of living (energy poverty, innocent arrears);

- support infrastructural interventions aimed at improving living conditions for individuals with disabilities and serious limitations of their independence (e.g., elderly assisted with the use of ambient assisted living technology);

- tighten the requirements of the registry of social housing beneficiaries to tackle frauds, improve management processes and facilitate actual access to social housing for the most disadvantaged groups. ${ }^{47}$

It is clear that the platform developed by the Capacity Building project fits consistently and creatively with this scenario, as it intends to support and implement schemes and measures by way of the resources provided by the EU structural funds. It should also be noted that these instruments can be combined with local synergies and the interventions provided under the National Operational Programme Metropolitan Cities, which has among its objectives the implementation of urban regeneration measures aimed at facilitating the social inclusion of residents. The regional administrations and the metropolitan municipalities can play a relevant role in the creation of financial engineering instruments and use their growing expertise to combine experiences and skills to fully assess housing needs and requirements, identification of range of beneficiaries and eligibility criteria. Such will be some of the areas to be addressed by the Capacity Building project. 


\subsection{Housing microcredit: the French case}

\subsubsection{Introduction}

In 2013, the Caisses d'Epargne launched a pilot programme to develop housing microcredits; namely, personal loans for disadvantaged owneroccupiers to help them finance their refurbishment work. Its three objectives are to fight energy poverty, combat insalubrity and adapt housing to the needs of people with disabilities. At the end of July 2014, the Caisses d'Epargne had provided 220 housing microcredits, in close collaboration with regional actors involved in improving housing conditions for vulnerable groups. Although housing microcredit is still at an early development stage, current experimentation opens new scenarios, discussions and collaboration between banks, NGOs and public authorities. It also illustrates the flexibility of personal microcredit as a tool to promote social inclusion.

\subsubsection{Context of the experimentation}

General overview of personal microcredit in France

France is a pioneer in developing personal microcredit on a large scale. Since the implementation of a national guarantee fund in 2005, the number of microcredits provided and actors involved in the supply chain have significantly increased. In 2013, around 13,000 personal microcredits were provided, of which more than 30 per cent were by the Caisses d'Epargne. ${ }^{48}$ Personal microcredit is defined by French law as a loan dedicated to finance social inclusion projects for the benefit of individuals, excluded from mainstream banks, who can take advantage of customised coaching provided by a social partner. Although in 2005 it was exclusively a tool dedicated to employment policy, all social purposes are now eligible under the programme, including housing. ${ }^{49}$ The loan amounts vary between $€ 300$ and $€ 5,000$, with a 50 per cent public guarantee. Following eight years of rapid growth, personal microcredit has now entered a new development phase in France. Recent trends show increased synergies with the traditional banking sector, the emergence of new types of stakeholders and experimentation focusing on specific social needs. Housing microcredit is an emblematic example of this diversification.

Within this national scheme, the Caisses d'Epargne have developed their own microcredit programme. They operate through a network of associations called Parcours Confiance. ${ }^{50}$ Its mission is to provide access to finance to people excluded from the mainstream banking 
circuit. It is also a "laboratory" of social and financial innovation, which allows Caisses d'Epargne to propose financial engineering instruments to respond to unmet social needs. The underlying philosophy of Parcours Confiance is to assess vulnerable clients' creditworthiness through customised tools and in-depth budget and social analysis, whereas nowadays, conversely, most banks rely on highly computerised processes, using automated credit scoring. This is made possible by establishing close ties with its social partners (non-profit organisations, social workers, etc.), which pre-select the applications and bring in their social inclusion expertise. Prior to the interventions, the social workers ensure that available welfare benefits are activated; according to a "subsidiarity" principle, microcredit should not replace any available forms of social aid. A typical process would unroll in any of the following ways: a partner identifies a financing need; a young man is offered a job but cannot accept it unless he buys a car as he lives far away; a woman wants to move to another home as she has troubles with her partner; a family has to face an unexpected death and struggles to pay the funeral expenses. Parcours Confiance steps in, assesses creditworthiness and decides whether to finance the project or not. In case of refusal, a viable alternative solution is proposed. On the other hand, if the loan is granted, Parcours Confiance closely monitors the reimbursement process in order to prevent any difficulties the client could face.

Parcours Confiance employs a total of 70 managers and loan officers. It relies on Caisses d'Epargne IT for credit management (release of funds, credit monitoring, etc.) but uses also its own dedicated software, which includes information generally not available in banking databases: partners, in-depth budget analysis, social performance (possibly to monitor project completion) and so on.

\section{Energy poverty: a rising problem}

The activity of Caisses d'Epargne in the housing microcredit sector finds its roots in the increased solicitations by local partners, mainly with regard to energy poverty. Energy poverty refers to households who are unable to afford to keep the home warm at reasonable cost. It is a major and growing issue in Europe, as many people struggle to pay their energy bills due to low income. This can result in unpaid energy bills, or arrears, self-disconnecting, disease linked to the cold, dampness and/or mould. Those most likely to fall into the energy poverty spiral are found in social housing but also increasingly amongst poor owner-occupiers, in particular in rural areas. The latter are often left out of public energy-efficiency programmes, although they represent a large part of the population. It is 
estimated, in fact, that around 300,000 homes in France are in the hands of low-income owner-occupiers. ${ }^{51}$ Since 2012, the French public authorities have implemented a national policy to tackle energy poverty, in which financial support can be channelled towards vulnerable groups, namely low-income owner-occupiers. This national programme led to the creation of networks of non-profit or public institutions that are able to mobilise social, administrative and technical engineering to carry out a global diagnosis of the specific housing needs and ensure complete support in all phases of refitting. However, despite public support lowincome households often find it hard to finalise the financing of the refitting that would end or alleviate energy poverty; finding an adequate source of financing can be an insurmountable obstacle indeed. In order to tackle this issue, a local savings bank, Caisse d'Epargne Bretagne Pays de Loire, initiated some pilot projects with local partners active in social housing. After successful testing, all Caisses d'Epargne got involved, with different levels of maturity.

\subsubsection{Main characteristics of housing microcredit}

\section{Target group}

As for traditional personal microcredit, eligible clients consist of financially excluded individuals; that is, people who cannot access credit from mainstream banks: low-income subjects (people on welfare, working poor); people without credit history (immigrants, young people, etc.) or bad credit history; people affected by social difficulties (divorce, illness, isolation, Roma community, etc.); labour-related difficulties (unemployment, precariousness, etc.); difficulty using financial services (financial illiteracy, etc.). More precisely, housing microcredit targets owners-occupiers. This is the main difference from traditional personal microcredit: the former represents a marginal part of the Caisses d'Epargne's microcredit portfolio. Another difference is that the clients' average income and reimbursement capacity is slightly higher here, although they could not manage to fund the projects on their own nor access the mainstream credit distribution chain.

\section{Amount, duration, cost}

The amount and duration of microcredits had to be adapted to the new types of projects financed. Housing microcredit provides for loans in the maximum amount of $€ 10,000$, whereas other personal microcredits are limited to $€ 5,000$. The duration can be up to 72 months, which is longer than traditional personal microcredit. A specific agreement was 
negotiated between the FNCE and the national public bank Caisse des Dépôts et Consignations (CDC), which manages the national guarantee fund for personal microcredit. Following this agreement, housing microcredits are eligible for public guarantees even if the amount exceeds $€ 5,000$. More recently, the FNCE developed a new partnership with one of the major actors involved in the improvement of housing conditions in France, the Fondation Abbé Pierre. Through this new agreement, the Caisses d'Epargne will provide a new guarantee line for housing microcredits up to $€ 25,000$.

For these microcredits, the Caisses d'Epargne offers an affordable interest rate, around 3 per cent. For other microloans it charges a fixed interest rate. There are no - or very low - fees and the beneficiaries enjoy free technical assistance.

\section{Eligible works}

Eligible works for financing are interventions to improve energy efficiency (building insulation, boiler replacement, etc.), upgrade to legal standard (on-site sanitation, ventilation, electrical installations, etc.), reduction of unhealthy housing and refitting of housing to meet the needs of the disabled.

\section{Credit assessment methodology: combining energy efficiency and} financial expertise

Creditworthiness assessment had to be adapted, too. A traditional personal microcredit assessment would include a deep analysis of revenue and charges, along with an assessment of the customer's social situation, with a customised approach as described above. In the case of housing microcredit, the traditional assessment is completed by carrying out a housing condition diagnosis, which includes an evaluation of the minimum essential interventions to be executed. As for energy poverty microcredit, there is an assessment of the expected energy improvements. In other words, the loan officer analyses more profoundly the energy costs on the household's budget, according to the technical energyefficiency diagnosis made by the partner. In case of households with an excessive energy bill, the cost of the interventions should be offset by the savings generated; in the event that households do not heat their homes because it is too costly, a strict budget must be followed, so that they can develop their reimbursement capacity. In all cases, strict and customised credit assessment is a necessary condition to avoid client overindebtedness. 


\subsubsection{A shared-value approach}

\section{Expected impacts}

This experiment will have three kinds of impacts: for society, for the beneficiaries and for the Caisses d'Epargne. In fact, housing microcredit combines a "triple bottom line" approach (people, profit, planet), as it is an economic tool designed to generate both social and environmental value. A specific report will be prepared in order to analyse these impacts.

\section{Environmental impact}

Reducing energy consumption and dependency is a major objective for our societies. Meeting this challenge requires the implementation of major energy-efficiency programmes that take into account the private housing sector; namely, owner-occupiers. The strong increase in precariousness since the 2008 economic crisis, amongst owners especially, calls for new financial approaches.

\section{Impact on the beneficiaries}

Social exclusion combined with indecent, insalubrious and substandard housing has formidable consequences for families' daily life. Children

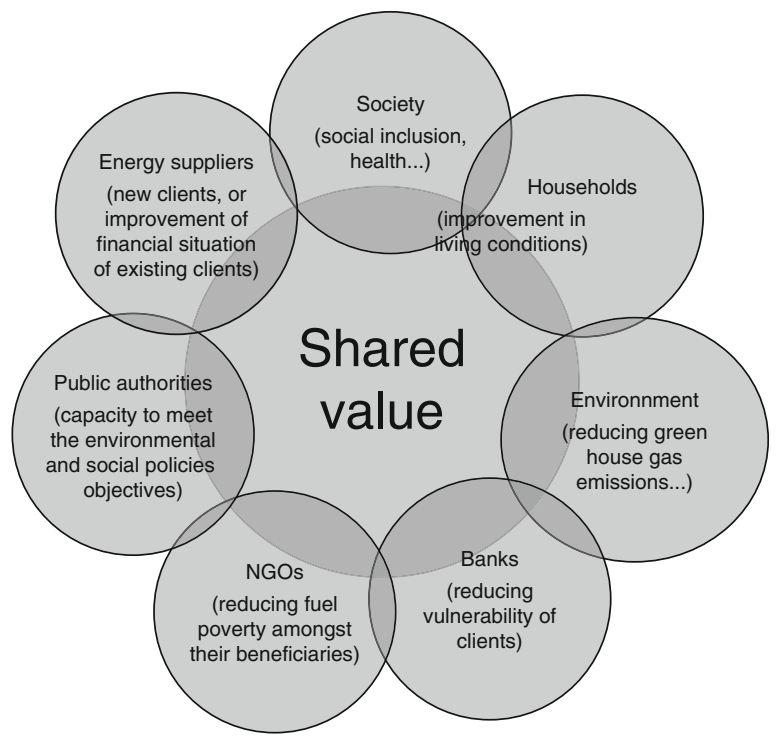

Figure 4.1 Shared-value approach

Source: Authors' elaboration. 
are often the first victims of this situation, from a health standpoint (resurgence of illnesses such as tuberculosis or lead poisoning) but also in terms of educational and developmental progress (absenteeism, academic delays). Parents confined to such environments may experience helplessness, with consequent desocialisation processes or difficulties committing themselves to an active job search.

\section{Financial impact}

One of the main issues to be evaluated through this experiment is the actual loss ratio of this kind of microcredits. According to the first budget and asset data analysed, the loss ratio should be far lower for housing projects than in the case of loans for mobility or employment purposes.

\section{Sustainability: a multistakeholder approach}

The sustainability of the energy poverty microcredit model relies on a multistakeholder approach, where each actor contributes according to the potential advantage to be obtained. The objective is to control energy expenditure for the low-income households through contributions provided by a large pool of stakeholders.

\subsubsection{Lessons learned: first insights}

\section{An important demand}

The first months of programme experimentation confirmed that housing microcredit can provide an effective response to a growing need. Finding partners and eligible projects to be financed was relatively easy. The main challenge is to improve the efficiency of these new partnerships: combining financial, housing and social expertise requires specific know-how. That is why the programme took time to take off. Once partnerships are operational, the acceptance rate seems to be higher than for traditional personal microcredit: around 80 per cent of applications are accepted.

\section{Clients' profile}

Currently, most applicants are people over 50 years old. The oldest client is 93. In this case, age is the main reason why these subjects are excluded from credit. Other clients are households under the poverty line but that nonetheless manage to reimburse around $€ 100$ a month.

\section{Types of projects}

Housing microcredit was designed to respond to three types of needs: energy poverty, insalubrity and adaptation of housing to the needs of 
Table 4.5 Contribution for different stakeholders

Actors involved Contribution

National and local Improving housing conditions is a major issue for public authorities policymakers, especially regarding energy efficiency, which is a major step for achieving a low-carbon economy and reducing energy spread within our societies. The social and environmental impacts expected justify the involvement of national and local public authorities. Public authorities' contribution consists in activating the national guarantee fund (50 per cent guarantee on microcredits) and support partners, which provide energy-efficiency diagnosis and subsidies that absorb part of the works' costs

Banks The Caisse d'Epargne contributes by providing experienced staff to Parcours Confiance and by absorbing the credit management-related costs (back office, IT, etc.), for the microcredit is on its balance sheet. Backing the credit activity with a major local bank gives the possibility of pooling resources and reducing costs

Expert partners Specialised social housing networks see microcredit as a way to diversify their financing tools for low-income households. In many cases, refurbishment projects would not be possible without microcredit

Clients The clients' contribution consists in paying loan costs and interest

Source: Authors' elaboration.

the disabled. Alleviating energy poverty seems to be the main drive behind this type of microcredit; it is the business line which developed most rapidly. Reporting analysis highlights three broad types of needs, with different financial levels:

- energy-efficiency interventions: $€ 16,000$ on average, including $€ 5,000$ microcredit;

- work to make dwellings compliant with regulatory standards: $€ 25,000$ on average, including $€ 7,000$ microcredit;

- work to upgrade insalubrious housing: $€ 30,000$ on average, including $€ 9,000$ microcredit.

\section{Some obstacles}

Following early experiences, upgrade of insalubrious housing has proved to be quite prohibitive and hard to finance through microcredit. 
In many cases, it is difficult to match the high level of work needed with the low reimbursement capacity of the borrowers. To really develop these financing schemes, new forms of financial supports should be found, whether private or public (guarantees, grants, etc.). Another issue is the lengthening of reimbursements, as borrowers, who are often at an advanced stage of life, can unexpectedly pass away or suffer from infirmity. In order to ensure the project's viability, financial security mechanisms, such as insurance subscriptions or third-party guarantees, should be developed for microcredits exceeding €10,000.

\section{New stakeholders, mainly suppliers}

One innovative aspect of this experiment is the partnership with new actors, such as energy suppliers. The objective is here to help households reduce their energy bill through increased energy efficiency. New stakeholders such as insurance companies or other suppliers may be interested in joining the pool of partners in the future.

\section{Notes}

1. Although the chapter has been prepared by the authors jointly, Sections 4.1 and 4.2 have been written by Giovanni Nicola Pes, whereas Section 4.3 by Paolo Rita, Sections 4.4.1-4.4.3, 4.4.5-4.4.7 were written by Fabrizio Santoboni, Section 4.4.4 by Pasqualina Porretta, Section 4.5.1, 4.5.2, 4.5.4 by Fulvio Pellegrini, Section 4.5.3 by Alessandro Cardente and Section 4.6 was written by Perrine Lantoine.

2. According to the definition provided by the UN, microfinance can refer to "loans, savings, insurance, remittance services, micro-loans and other financial products destined to low-income customers". According to another, more general, definition proposed by an Italian academic (Viganò, 2004), microfinance consists of the "promotion and dissemination of forms of financial intermediation dedicated to underserved customer sectors, which cannot be catered to through the traditional methods and channels, due to their size, low income or lack of financial education".

3. Ibid.

4. Banque de France (2012), "Rapport annuel de l'observatoire de la microfinance". Latest edition, Exercise 2012.

5. Banque de France (2011), "Colloque international sur la Microfinance", July.

6. http://www.microcreditoitalia.org/capacitybuilding/.

7. See, for example, Christine Poursat in "Dossier thématique: Diversification des produits", Portail de la Microfinance, January 2014. See also Marc Labie, Carolina Laureti and Ariane Szafarz, "Flexible products in micro-finance: overcoming the demand-supply mismatch", Centre Emile Bernheim (CEB) Research Institute in Management Sciences, Working Paper no. 13/044, December 2013. 
8. In particular, we refer here to the workshop "Micro-finance and the new programming period 2014-2020", held in Rome in April 2014, which was attended by representatives of the regions involved in the convergence programme, the main bank, insurance and leasing associations (ABI, ANIA, Assilea), market operators, academics and politicians. The results of the workshop were published by the Italian National Agency for Microcredit (www. microcreditoitalia.org/capacitybuilding).

9. In developing countries (PVS) microleasing is more widespread than in European countries, esp. in rural areas.

10. Ruth Stewart et al. (2012), "Do micro-credit, micro-savings and microleasing serve as effective financial inclusion interventions enabling poor people, and especially women, to engage in meaningful economic opportunities in low- and middle-income countries? A systematic review of the evidence". EPPI, Centre - The Evidence for Policy and Practice Information and Coordinating Centre, http://r4d.dfid.gov.uk/pdf/outputs/systematicReviews/Microcredit2012StewartReport.pdf.

11. The EPPI-Centre (http://eppi.ioe.ac.uk) is part of the Social Sciences Research Unit of the Institute of Education, University of London. The centre develops methods for systematic reviews and abstracts, by carrying our reviews and providing orientation and training.

12. The 84 relevant studies took place in 33 different countries: Bangladesh, Bolivia, Bosnia and Herzegovina, Côte d'Ivoire, Ecuador, Egypt, El Salvador, Ethiopia, Ghana, Haiti, India, Indonesia, Kenya, Madagascar, Malawi, Mexico, Mongolia, Morocco, Nicaragua, Nigeria, Pakistan, Paraguay, Peru, Philippines, Syria, Tanzania, Thailand, Tunisia, Uganda, Uzbekistan, Vietnam, Zambia, Zimbabwe.

13. Ruth Stewart et al. (2012), pp. 100-101.

14. Within the classic division between microfinance "for enterprises" and "social" microfinance (according to art. 111 of the Unified Banking Act), microleasing is a definitely product dedicated to the former.

15. Oxford Economics (2011), "The use of leasing amongst European SMEs", Leaseurope, Brussels. Leaseurope, the European federation of leasing companies, represents 44 associations from 34 countries.

16. According to the applicable EU legislation (recommendation 2003/361/EC) of the European Commission of 6 May 2003 concerning the definition of microenterprises, small and medium-sized enterprises), a microenterprise is defined as an enterprise employing fewer than 50 persons and whose annual turnover and/or balance sheet total do not exceed $€ 2$ million. In the 25 country EU, around 23 million SMEs provide around 75 jobs and represent 99 per cent of the total number of enterprises. With specific regard to microenterprises, Italy is the European country where enterprises with less than ten employees play the most relevant role in terms of added value and employment: in 2010, the share of added value created by such enterprises in the country was equal to 33 per cent (around 14 points higher than the European average) and up to 50 per cent if we consider only tertiary and construction sectors. Bank of Italy (2013), Economic and Financial Issues, "Micro-enterprises in Italy: an introductory analysis", April, pp. 5-6.

17. See the declarations of the most prominent players in the international leasing sector in the article "Built to last" in Leasing Life, January 2012, 
according to which, SMEs engaged in the manufacturing sector account for the highest number, almost a fifth of the total.

18. IAIS (2007), p. 10.

19. In this regard, it should be noted that the IAIS itself specifies that "microinsurance does not include government social welfare as this is not funded by premiums relating to the risk, and benefits are not paid out of a pool of funds that is managed according to insurance and risk principles. For the same reason, it does not include emergency assistance provided by governments, for example, in case of natural disasters (floods, fires) in low-income townships. However, as a risk manager of last resort, the State may determine that there is a need to sponsor access to micro-insurance for the most underprivileged subjects through redistributive practices. There are cases where the State plays a stronger role in fully funding schemes, but these could only be considered micro-insurance if they are run according to insurance principles" IAIS (2012), pp. 11-12.

20. Housing policies are part of the policies for social services of general interest (SSGI). For a further elaboration on the concept of social housing, see European Commission (2010), Second biennial report on social services of general interest. Commission Staff Working Document, Brussels, 22 October 2010, SEC (2010) 1284 final.

21. In terms of increase in employment opportunities originating from the recovery of the social housing market.

22. The total forced evictions ordered in 2013 amount to 73,385. See Ministry of the Interior - School of the Administration of the Interior - General Statistics Office (2014), Forced evictions in Italy: performance of eviction procedures in residential buildings 2013, Statistics Notebook no. 1, Rome.

23. Social housing represents an integrated answer to sustainability. Today social housing involves around 25 million houses in Europe, half of which are characterised by energy consumption exceeding $150 \mathrm{kWh} / \mathrm{m}^{2} /$ year. To promote energy requalification of these buildings means first of all reducing $\mathrm{CO}_{2}$ emissions as well as the poverty originating from high energy costs. In addition, these measures can also stimulate a more environmentally friendly and competitive economy. For further investigations on this issue, see Forcella D. (2013), European green microfinance: a first look, EMN Research 2013, Brussels.

24. These structural measures entail broad benefits in terms of energy savings and the possibility of a more equitable distribution of savings among tenants, social housing associations and owners, which could be invested to finance further modernisation and improvement of buildings. In this context, we should take into account the provisions introduced by EU directive 2012/27/ of the European Parliament and Council of 25 October 2012 on energy efficiency, amending directives 2009/125/EC and 2010/30/UE and cancelling directives 2004/8/EC and 2006/32/EC with regard to energy efficiency of buildings in the member states, including renovation of buildings, as the existing building stock represents the sector with the greatest potential for energy savings.

25. The situation is quite variegated: figures go from over 30 per cent in the Netherlands to 2 per cent in Spain, through a composite and different scenario across the EU member states, which can be explained only by referring to different welfare systems and historic developments. Moreover, the 
same percentages, although similar, can be the results of different measures taken over time.

26. The most commonly accepted definition of social housing is the one provided by the Cecodhas Housing Europe - the European Federation of Public, Cooperative and Social Housing, which defines it as "the group of activities aimed at providing affordable housing, by way of precise allocation rules, to support households who struggle to access housing at market conditions, either because they are unable to access credit or because they are affected by particular issues". Dwellings built, sold or rented according to the principles of the free market, therefore, do not fall under the category of social housing. Government support to social housing may assume different forms, such as government-guaranteed loans, grants for the payment of interests on loans, guarantees or fiscal incentives. Public support may be provided by the central government and local government authorities to tenants or providers, to finance both the construction of new buildings and maintenance of existing buildings. Unlike other types of accommodation, social housing is typically assigned to the weakest and most vulnerable segments of the population, according to selection criteria established by central or local government authorities, which take into account income limits and/or implicit or explicit allocation mechanisms where points are assigned according to the social and economic status of the applicants, such as students, elderly, disabled, immigrants, etc. See http://www.housingeurope.eu/.

27. For a more articulated discussion on meaning and general characteristics of the forms of social housing in Europe, see Cechodhas (2011), Housing Europe review 2012. The nuts and bolts of European and social housing systems, Brussels and EC (2013), Directorate-General for Internal Policies, Social housing in EU, Brussels.

28. These are supported by public incentives and may result in a subsequent division of ownership between partners or maintain the property undivided.

29. These houses are mostly owned by cooperatives, social housing providers and private individuals who collaborate with the cooperatives/organisations for the maintenance of common spaces and activities.

30. This is the direction followed also by all urban regeneration interventions whose objective is to recover housing stocks, especially in urban centres, without extending building space and urban sprawl.

31. It goes without saying that all the aforementioned policies are aimed towards social inclusion. They explicitly refer to target groups characterised by poor conditions and severe social distress.

32. This group includes also government-owned houses already occupied but restored for the above purpose.

33. For a further insight, see http://www.habitat.org/housing_finance/best_practices.aspx; http://www.citiesalliance.org/. The definition accepted herein indicates housing microfinance as follows: Housing micro-finance (HMF) is primarily the provision of unsecured microcredit, but may include other related financial services - such as access to savings, remittances, and micro-insurance to meet the demand of low-income households to repair or improve their existing homes or build their own homes incrementally one loan at a time. These loans may also require mandatory savings or serialised assets and other collaterals. Credit 
assessment is similar to the cash flow analysis and character investigation processes applicable to unsecured small business loans to individual entrepreneurs. The process often includes documentation to verify residence, a list of building materials to be purchased or that have already been saved by the borrower, and an estimate for specialised labour. Character investigation may also include questions on the borrower's social capital to enhance the incremental building process: social networks, contacts with NGOs or building materials suppliers, and free skills available to the household that can support the self-builder. See http://www.hofinet. org, a specialised website connected with financial institutions under the World Bank.

34. See, for example, http://www.affordablehousinginstitute.org/?mtheme_ portfolio=identifying-and-upgrading-in-ulaanbaatar, or Kihato M. (2013), State of housing: micro-finance in Africa, Centre for Affordable Housing Finance in Africa, Housing Finance Information Network, Philadelphia, USA.

35. Housing as a construction practice.

36. For a detailed reading, see Bank of Italy (2014), Consolidated act on banking and construction laws, updated version to Legislative Decree 4 March 2014, no. 53.

37. Social housing is regarded in Italy as a policy for the development of subsidised housing and access to decent and affordable housing by segments of the population that are currently excluded (also through the purchase of property). The Italian legislation (ministerial decree on infrastructures, 22 April 2008) provided a comprehensive and detailed definition of the term: "Definition of social housing for the purpose of exemption from notice requirements of State Aid, according to arts no. 87 and 88 of the del Treaty establishing the European Community", pursuant to art. 5 of law no. 9/2007, paragraph no. 2 of art. 1, "social housing", defines it as "housing tenure for residential use and permanently leased, which fulfils functions of general interest, in the protection of social cohesion and with the aim of reducing housing problems of disadvantaged individuals and households, who cannot afford house rentals on the free market. Social housing is a key element of the residential housing system constituted by the total of housing services aimed at the fulfilment of primary needs; Paragraph 3 . The definition under paragraph No. 2 include houses built or recovered by public and private operators, by way of public grants or incentives - such as tax exemptions, allocation of areas or buildings, guarantee funds, planning facilitations dedicated to temporary house rental for a period of at least eight years and to ownership as well; Paragraph 4 . Social and residential housing is provided by public and private operators through the provision of houses to be leased, which must be allocated the largest part of available resources as well as support to facilitate home ownership, pursuing the integration of different sectors of the community and contributing to the improvement of the recipients' living conditions; Paragraph 5. As a service of general economic interest, social housing constitutes the additional planning standard to be ensured through free assignment of areas or dwellings, according to methods established by regional legislations". Art. 2, paragraph 7 "Social housing must be built in accordance with principles of environmental sustainability and energy savings, using, where applicable, alternative energy sources". 
38. Including the interventions under the National Operational Programme for Metropolitan Cities, which will act on the same issues in collaboration with the regional operational programmes financed by the European Investment Fund and the European Regional Development Fund.

39. Law decree no. 47 of March 2014. This decree, known as House Plan or Lupi Decree, introduces new provisions on social housing. In light of the strong constraints in access housing affecting vulnerable segments of the population, this decree provides, among other measures, for the increase in financial provisions of a number of funds created as support instruments, partly similar to social microcredit. They are the solidarity fund for mortgages to buy first homes, the fund to access loans to buy first homes, the support fund for leased houses and the guarantee fund to cover the risk of default of unreliable tenants. For an in-depth insight on the Italian legislation on housing, please refer to the document prepared by the Chamber of Representatives, http://www.camera.it/temiap/temi17/Am0050.pdf.

40. It should be mentioned here that, unlike microcredit dedicated to microenterprises, the financial allocation of social microcredit amounts to just $€ 10,000$; this has some specific consequences and effects on the financial instruments and their use within broader schemes. For example, limits to the type of interventions to be financed and their scope.

41. Both in the form of undivided property (with the presence of tenants) and organisation of individual property divided among the members of the cooperatives providing social housing.

42. Federcasa, Federabitazione-Confcooperative and Legacoop Abitanti are members of the CECODHAS Housing Europe - the European Federation of Public, Cooperative and Social Housing. Established in 1988, it is a network of 42 national and regional federations gathering about 41,400 providers in 22 countries, which manages over 25 million homes, about 12 per cent of the existing dwellings in Europe. http://www.housingeurope.eu/.

43. http://www.sunia.it.

44. http://www.uppi.it.

45. Sustainable energy and quality of living (to promote the transition towards a low carbon economy in all sectors); improve energy efficiency for end users and promote smart energy; reduce energy consumption in residential and commercial buildings, public buildings or buildings open to the public.

46. Climate and environmental risks (promote adaptation to climate changes, risk prevention and management); risk prevention and mitigation and adaptation to climate changes.

47. Partnership agreement 2014-2020, Italy, Annex Expected Results. Actions, 7 April 2014.

48. Caisse des Dépôts et Consignations, Bilan du microcrédit personnel au 4ème trimestre 2013 (February 2014).

49. Law no. 2010-737 of 1 July 2010 brought credit reform to completion: "Les prêts destinés à participer au financement de projets d'insertion accordés à des personnes physiques confrontées à des difficultés de financement, dont les capacités de remboursement de ces prêts sont jugées suffisantes par les prêteurs et qui bénéficient d'un accompagnement social. Ces prêts sont accordés afin de permettre l'accès, le maintien ou le retour à un emploi. L'inscription des personnes intéressées au fichier national recensant les 
informations sur les incidents de paiement caractérisés liés aux crédits accordés aux personnes physiques pour des besoins non professionnels prévu à l'art. L. 333-4 du code de la consommation ne peut constituer en soi un motif de refus de ces prêts. Ces prêts peuvent également être accordés pour la réalisation de projets d'insertion sociale qui ne sont pas directement liés à un objectif professionnel".

50. www.parcours-confiance.fr.

51. The national public policy designed in 2010 for the $2010-2017$ period identified 300,000 poor owner-occupiers facing fuel poverty, especially in rural areas ("plan de précarité énergétique", 26 January 2010, and "programme Habiter Mieux").

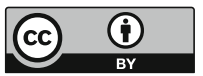

Except where otherwise noted, this work is licensed under a Creative Commons Attribution 3.0 Unported License. To view a copy of this license, visit http://creativecommons.org/licenses/by/3.0/ 